\title{
ANALYSIS OF WATER SURFACE AND FLOW DISTRIBUTION FOR THE DESIGN FLOOD AT A PROPOSED HIGHWAY CROSSING OF THE SABINE RIVER NEAR TATUM, TEXAS
}

By J.J. Gilbert and D.R. Myers

U.S. GEOLOGICAL SURVEY

Water-Resources Investigations Report 88-4231

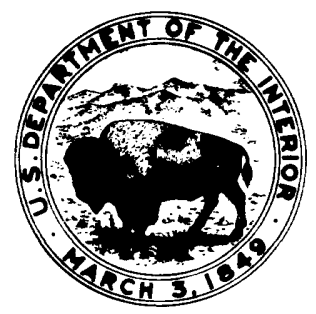

Prepared in cooperation with the TEXAS STATE DEPARTMENT OF HIGHWAYS AND PUBLIC TRANSPORTATION 


\author{
\begin{tabular}{l|l} 
DEPARTMENT OF THE INTERIOR
\end{tabular} \\ MANUEL LUJAN, JR., Secretary \\ U.S. GEOLOGICAL SURVEY \\ Dallas L. Peck, Director
}

For additional information write to:

District Chief

U.S. Geological Survey

8011 Cameron Rd.

Aust in, TX 78753
Copies of this report can

be purchased from:

U.S. Geological Survey

Books and Open-file Reports Section

Federal Center, Bldg. 810

Box 25425

Denver, CO 80225 


\section{CONTENTS}

Page

Abstract-_-

Introduction--.-.--

Purpose and scope---_-

Acknowledgments-1.-

Description of the study area-

Flood records--

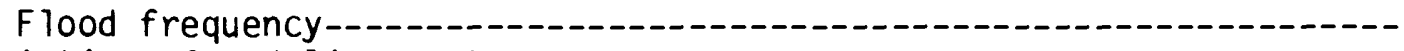

Description of modeling system-_.-.

Governing equations-_.

Solution technique--_-

Modeling procedure-----

Preliminary computations---

Study-reach definition---

Computed water-surface-altitude profiles--

Topographic data--

Design of the finite-element network--

Steady-state approximation-.-

Boundary conditions-_-_- 12

Water surface and flow distribution-_.

Sensitivity analysis--

FESWMS (finite-element surface-water modeling system) model-_..--.-- 18

Downstream-boundary specification-_..-_......- 18

Manning's roughness coefficient (" $n$ ") value-.............. 20

Discharge--.-. 20

Base eddy viscosity---_-_-_- 20

WSPRO (water-surface profile) model-1..-...- 24

Simulation of alternate design-_. 29

Network modification-_. 29

Results of the simulation-- 29

Simulation of natural conditions-- 29

Network modification-_- 32

Results of the simulation--.-- 32

Backwater and drawdown-_.

Summary and conclusions-_- 35

Selected references-_- 36

\section{ILLUSTRATIONS}

Figure 1. Map showing location of the study area and the proposed Texas Highway 43 crossing of the Sabine River near

Tatum, Texas-.-.- 3

2. Diagram of coordinate system axes-_...- 6

3. Map showing finite-element network and lines of topographic surveys-_...-...-..- 10

4. Map showing computed water-surface contours for the proposed design of the highway crossing-_-_.-. 15

5. Graph showing computed velocities within the bridge openings for the proposed design-_.-. 16 


\section{ILLUSTRAT IONS--Cont inued}

Page

Figure 6. Graph showing computed unit discharge within the bridge

openings for the proposed design-....

7-12. Maps showing lines of equal change in computed watersurface altitude for a:

7. 1-foot increase in the downstream-boundary

8. 15-percent increase in Manning's roughness

coefficient (" $n$ ") for all areas-....

9. 15-percent increase in Manning's roughness
coefficient (" $n$ ") for areas of the floodplain

on 1 y

10. 15-percent increase in discharge-................. 23

11. Change in the eddy viscosity from 150 to 20 feet squared per second-_....... 25

12. Change in the eddy viscosity from 50 to 20 feet

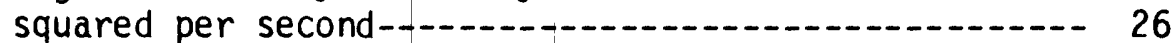

13-15. Graphs showing water-surface profiles computed using the WSPRO (water-surface profile) model:

13. With different starting water-surface altitudes at the downstream boundary

14. With a 15-percent change in Manning's roughness coefficient (" $n$ ")

15. With a 15-percent change in discharge-........ 30

16-18. Maps showing:

16. Computed water-surface contours for the alternate design of the highway crossing

17. Computed water-surface contours without the Highway 43 embankment in place.................. 33

18. Lines of equal backwater or drawdown for the

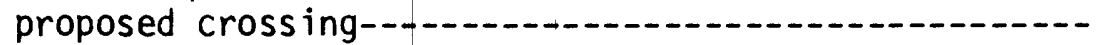

TABLES

Table 1. Embankment-opening widths for the existing, proposed, and alternate designs-...... 4

2. Discharge and water-surface altitudes of floods of specified recurrence intervals, Sabine River near Tatum--..-- 5

3. Values of Manning's roughness coefficient (" $n$ ") used in the proposed design simulation-_._. 13

4. Computed distribution of discharge among bridge openings for one- and two-dimensional analyses of the proposed design-_........ 13

5. Computed fall through bridge openings for the proposed

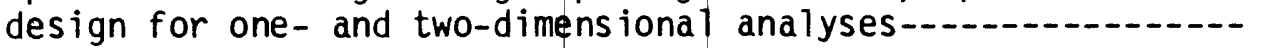




\section{METRIC CONVERSIONS}

Factors for converting inch-pound units to metric (International System) units are given in the following table:

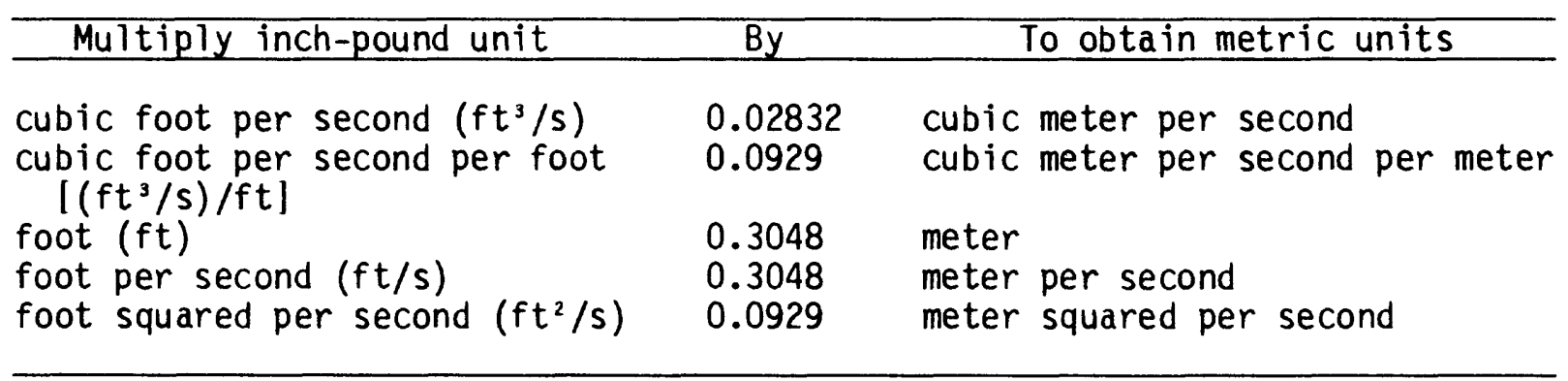

Sea Level: In this report "sea level" refers to the National Geodetic Vertical Datum of 1929 (NGVD of 1929)--a geodetic datum derived from a generâl adjustment of the first-order level nets of both the United States and Canada, formerly called "Mean Sea Level of 1929." 


\title{
ANALYSIS OF WATER SURFACE AND FLOW DISTRIBUTION FOR THE DESIGN FLOOD AT A PROPOSED HIGHWAY CROSSING OF THE SABINE RIVER NEAR TATUM, TEXAS
}

By

\author{
J.J. Gilbert and D.R. Myers
}

\begin{abstract}
The hydraulic effects of the proposed Texas Highway 43 crossing of the Sabine River near Tatum, Texas, were determined on the bas is of results from a two-dimensional finite-element surface-water-flow model. In planning the replacement crossing by the Texas State Department of Highways and Public Transportation, approximations of apportionment of flow among the openings and velocities within the openings were of concern. The model was used to simulate flow in the river floodplain system for the proposed design, an alternate design, and for the natural condition. The proposed bridge design by the State Department of Highways and Public Transportation consisted of a 320-foot main channel opening, four left overflow bridges with widths of $120,320,320$, and 280 feet, and one right overflow opening with a width of 440 feet. The alternate design consisted of a 950-foot main channel opening, three left overflow bridges with widths of 320,320 , and 280 feet, and one right overflow opening with a width of 200 feet. Preliminary one-dimensional computations were used as an aid in establishing the boundary conditions for the twodimensional analysis.

The analys is evaluates the interaction of complex hydraulic characteristics of varied features found at many multiple-opening highway crossings. Valid applications of accepted standard one-dimensional techniques would not reveal some aspects of the overall hydraulics of the crossing.

The simulation of the proposed design shows, among other things, which openings are the most productive per foot of bridge length. The results of the two-dimensional simulation of the proposed design indicate some differences in the apportionment of flow among the openings when compared to the one-dimensional proposed crossing computations. The alternate design results in computed water-surface altitudes which were slightly lower than those of the proposed design. The alternate design would require less modification to the existing embankment. Velocities computed within the openings and at the bridge abutments, using the two-dimensional model, were within the design specifications of the State Department of Highways and Public Transportion.

The simulations of the proposed and alternate designs indicate a lateral component of the water-surface slope at the embankment. Redistribution of flow across the floodplain also is indicated in both simulations. Some of the differences in the response between the two designs are affected by geometric features of the floodplain other than the embankment-opening geometry.
\end{abstract}




\section{INTRODUCT ION}

The design of a highway crossing over a wide floodplain is an intricate balance of embankment and bridge sections that conform to the design limits of the roadway and produce hydraulic conditions that are within design values. The use of FESWMS (finite-element surface-water modeling system), developed by the Federal Highway Administration and the U.S. Geological Survey, for twodimensional laterally averaged flow has contributed greatly to the confidence in complex highway-crossing design. Recent applications have shown that a calibrated model was verified by reproducing a later flood (Gilbert and Froehlich, 1987). The design analyst now has the ability to evaluate features and conditions which previously had to be neglected or lumped into another parameter.

The existing Texas Highway 43 crossing has five bridge openings, is considered to be inadequate, and is being redesigned for replacement. The proposed crossing has six openings formed by modification of the existing openings. In consideration of previous two-dimensional investigations, the Texas State Department of Highways and Public Transportation (SDHPT) initiated an evaluation of this crossing to test the adequacy of the proposed design.

\section{Purpose and Scope}

The purpose of this investigation is to describe the hydraulic characteristics associated with a proposed highway crossing of the Sabine River near Tatum, Texas. The hydraulic characteristics include apportionment of flow among openings, two-dimensional velocities at highway-embankment openings, and water-surface altitudes in the area. If any aspects of the proposed design showed potential for improvement, an alternate design was to be tested.

\section{Acknowledgments}

The assistance of Sawyer Wimberly, Texas State Department of Highways and Public Transportation, and Mike Fraher and Donald Harley, Federal Highway Administration, is gratefully acknowledged. Permission by landowners allowing land surveys on their property is very much appreciated.

\section{DESCRIPTION OF THE STUDY AREA}

The proposed highway crossing of the Sabine River is a reconstruction of the current (1988) Texas Highway 43 bridges and embankments about $4 \mathrm{mi}$ northeast of Tatum (fig. 1). The study area, which extends about 3 mi upstream and downstream from the highway crossing, is in Panola and Rusk Counties.

The main channel consists primarily of sand and shale and is subject to shifting, but is considered stable for the scale of this investigation. Overbanks generally are heavily wooded with some thick underbrush. Altitudes of the lowest points in the ma in channel range from $197 \mathrm{ft}$ near the downstream boundary to $211 \mathrm{ft}$ near the upstream boundary. Altitudes of the floodplain range from about $226 \mathrm{ft}$ in the eastern part of the study area to about 230 feet in the western part. Along the highway, floodplain altitudes are 


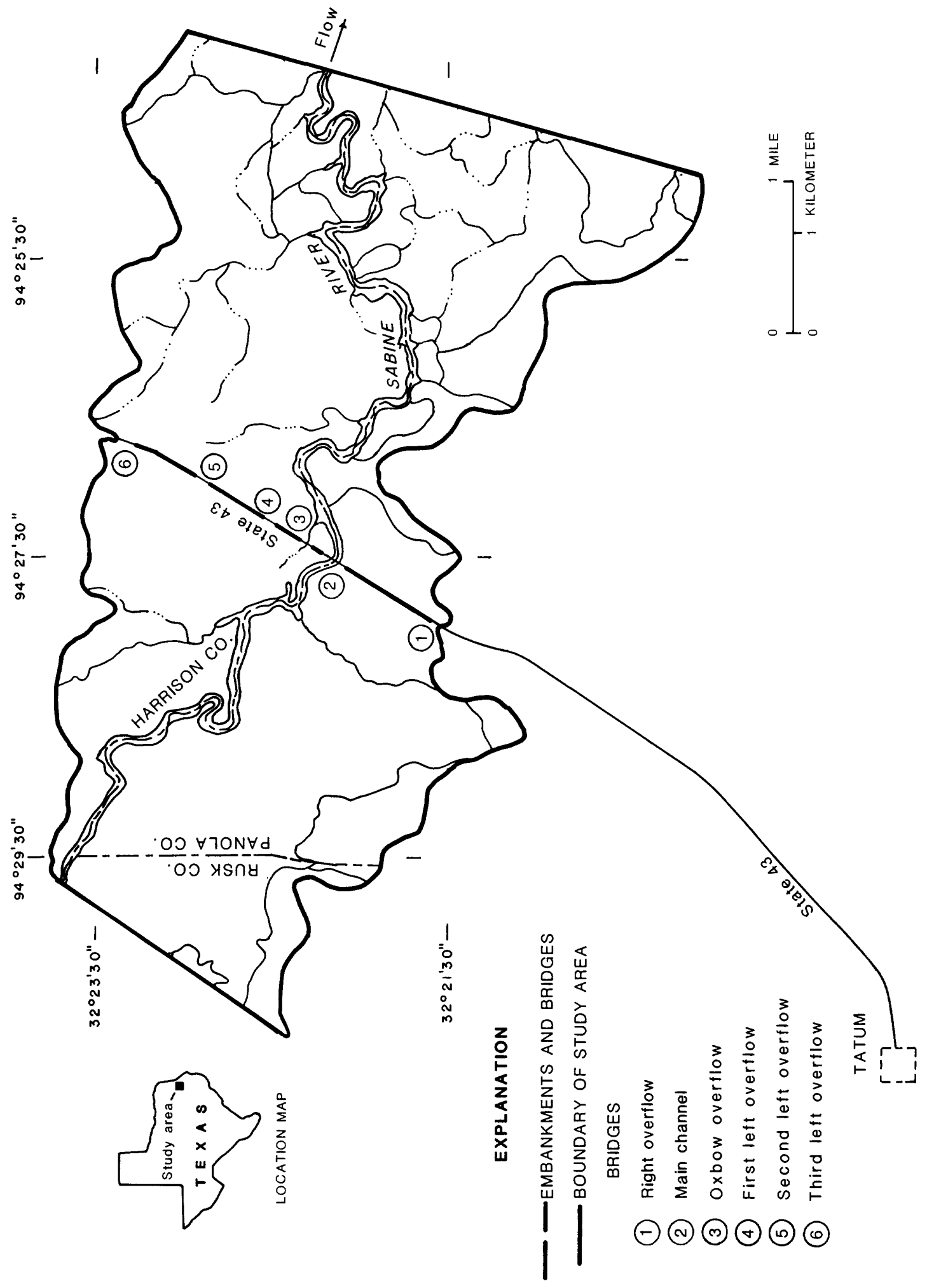

| 
slightly greater than $230 \mathrm{ft}$ at the right overflow and slightly less than 230 $\mathrm{ft}$ at the main channel and left overflow bridges. The width of the channe1, from high bank to high bank, ranges from 200 to $400 \mathrm{ft}$, generally increasing in the downstream direction.

Minor channels in the floodplain are relatively ineffective and were not modeled in detail. Spring Creek, which enters the floodplain on the left bank just downstream of the highway crossing, is bridged by the highway. Because flow from the Sabine River does not pass under this bridge for a flood of the design magnitude, it was not considered in the analysis.

The existing crossing has five openings, the main channel with a width of $950 \mathrm{ft}$, one right overflow bridge with a width of $200 \mathrm{ft}$, and three left overflow bridges with widths of 320,200 , and $240 \mathrm{ft}$. The proposed crossing has six openings: a 320-ft main channel opening, a 120-ft bridge over an oxbow channel originally spanned by the ma in channel bridge, a right overf low bridge with a width of $440 \mathrm{ft}$, and three left overflow bridges with widths of 320 , 320 , and $280 \mathrm{ft}$ ( $\mathrm{fig} .1$ ). In the proposed crossing, a 11 existing openings are modified except for the first left overflow (table 1 ).

Table 1.--Embankment-opening widths for the existing, proposed, and alternate designs

\begin{tabular}{lrrr}
\hline \multicolumn{1}{c}{ Opening } & \multicolumn{3}{c}{$\begin{array}{c}\text { Bridge width } \\
\text { (feet) }\end{array}$} \\
\cline { 2 - 4 } & Existing & Proposed & Alternate \\
Right overflow & 200 & 440 & 200 \\
Ma in channel & 950 & 320 & 950 \\
Oxbow overf low & 0 & 120 & 0 \\
First left overf low & 320 & 320 & 320 \\
Second left overf low & 200 & 320 & 320 \\
Third left overflow & 240 & 280 & 280 \\
& & & \\
\hline
\end{tabular}

\section{Flood Records}

Flood records at the Sabine River gaging station near Tatum begin in May 1884. The highest stage of record is $238.0 \mathrm{ft}$ above sea level, occurring on April 4, 1945. The discharge corresponding to this stage is estimated at $123,000 \mathrm{ft}^{3} / \mathrm{s}$. The second highest flood-stage record of about $236 \mathrm{ft}$ above sea level occurred in May 1884.

\section{Flood Frequency}

Data taken from the Geological Survey gaging station at Sabine River near Tatum were used by the SDHPT to estimate design discharges using the hydrologic-analysis procedure for a gaged site. The estimated discharges and associated water-surface altitudes from the stage-discharge relationship are given in table 2. The design flood considered for this study has a 50-year recurrence interval. 
Table 2.--Discharge and water-surface altitudes of floods of specified recurrence intervals, Sabine River near Tatum

\begin{tabular}{rcc}
\hline $\begin{array}{c}\text { Recurrence } \\
\text { interval }\end{array}$ & $\begin{array}{c}\text { Discharge } \\
\text { (cubic feet } \\
\text { per second) }\end{array}$ & $\begin{array}{c}\text { Altitude } \\
\text { above sea level } \\
\text { (feet) }\end{array}$ \\
\hline 10 years & 45,700 & 232.8 \\
25 years & 74,000 & 235.1 \\
50 years & 102,700 & 236.9 \\
100 years & 139,400 & 238.8 \\
\hline
\end{tabular}

\section{DESCRIPTION OF MODELING SYSTEM}

The FESWMS-2DH (finite-element surface-water modeling system for twodimensional flow in the horizontal direction), hereafter referred to as FESWMS, is a modular set of computer programs developed specifically for modeling surface-water flows where the flow is essentially two-dimensional in the horizontal plane (Lee and others, 1982). The system consists of data preprocessing and postprocessing utilities in addition to the central flow model.

Preprocessing programs are used to edit and plot input data and arrange them in appropriate formats for use by the flow model. Postprocessing programs are used to plot maps of velocity vectors, water-surface altitudes, and lines of equal difference in altitudes between simulations. The flow model solves the vertically-averaged equations of motion and continuity using the finite-element method of analys is to obtain the depth-averaged velocities and flow depths. A detailed description of the modeling system is beyond the scope of this report. Therefore, only the governing equations and a brief outline of the solution technique are presented.

\section{Governing Equations}

A fundamental requirement of any numerical model is a satisfactory quantitative description of the physical processes that are involved. The equations that govern hydrodynamic behavior are based on the concepts of conservation of mass (continuity) and momentum (motion). By integrating the three-dimensional equations over the water depth and assuming a constant fluid density, a set of three equations appropriate for modeling flow in shallow water bodies is obtained. Because the flow is assumed to be in a horizontal direction, it is convenient to use a right-hand Cartesian coordinate system with the $x$ and $y$ axes in the horizontal plane and the $z$ axis directed upwards as shown in figure 2. The $x, y$, and $z$ components of velocity are denoted by $u, v$, and $w$, respectively; $z_{b}$ is the bed or ground-surface altitude, $z_{s}$ is the water-surface altitude, $H$ is the depth of flow, and $t$ is time.

The depth-averaged continuity equation is

$$
\frac{\partial H}{\partial t}+\frac{\partial}{\partial x}(U H)+\frac{\partial}{\partial y}(V H)=0,
$$



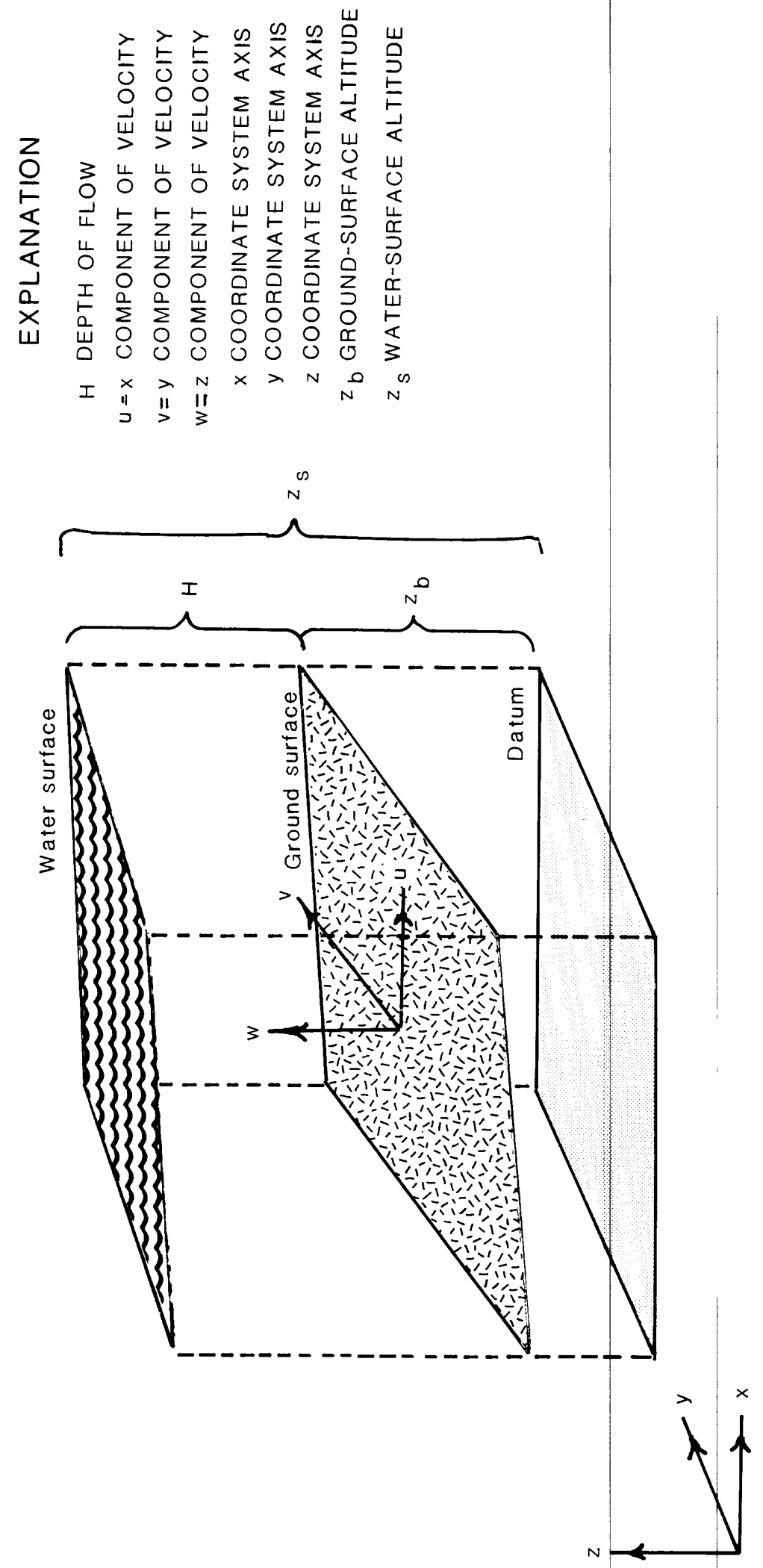

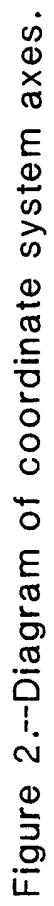


in which $U$ and $V$ are the depth-averaged values of the horizontal velocities $u$ and $v$, respectively. The depth-averaged conservation-of-momentum equation in the $x$ direction is

$$
\begin{aligned}
\frac{\partial}{\partial t}(H U) & +\frac{\partial}{\partial x}\left(\alpha_{u u} H U U\right)+\frac{\partial}{\partial y}\left(\alpha_{u v} H U V\right)+g H \frac{\partial}{\partial x}\left(H+z_{b}\right) \\
& -\Omega H V-\frac{\rho \alpha}{\rho} c_{w} W^{2} \cos \psi+c_{f} U\left(U^{2}+v^{2}\right) 1 / 2 \\
& -\frac{\partial}{\partial x}\left[\hat{\sim}_{v} H\left(\frac{\partial U}{\partial x}+\frac{\partial U}{\partial x}\right)\right]-\frac{\partial}{\partial y}\left[\hat{v}_{v} H\left(\frac{\partial U}{\partial y}+\frac{\partial V}{\partial x}\right)\right]=0,
\end{aligned}
$$

and the depth-averaged equation of motion in the $y$ direction is

$$
\begin{aligned}
& \frac{\partial}{\partial t}(H V)+\frac{\partial}{\partial x}\left(\alpha_{u v} H V U\right)+\frac{\partial}{\partial y}\left(\alpha_{v v} H V V\right)+g H \frac{\partial}{\partial y}\left(H+z_{b}\right) \\
& +\Omega H U-\frac{\rho}{\rho} C_{W} W^{2} \sin \psi+C_{f} V\left(U^{2}+V^{2}\right)^{1 / 2} \\
& -\frac{\partial}{\partial x}\left[\stackrel{\sim}{\sim} H\left(\frac{\partial U}{\partial y}+\frac{\partial V}{\partial x}\right)\right]-\frac{\partial}{\partial y}\left[\stackrel{\sim}{\sim} H\left(\frac{\partial V}{\partial y}+\frac{\partial V}{\partial y}\right)\right]=0 \text {, }
\end{aligned}
$$

in which $\alpha_{u u}, \alpha_{u v}, \alpha_{v v}=$ momentum correction coefficients (dimensionless),

$\Omega=$ Coriolis parameter (radians per second),

$g$ = gravitational acceleration (foot squared per second),

$\rho=$ density of water (slugs per cubic foot),

$\rho_{\alpha}=$ density of air (slugs per cubic foot),

$c_{W}=$ wind friction coefficient (dimensionless),

$c_{f}=$ bottom friction coefficient (dimensionless),

$\hat{v}=$ depth-averaged eddy viscosity (foot squared per second),

$W=$ local wind velocity (foot per second),

$\psi=$ angle between the wind direction and the positive $x$ axis (degrees), and

$t=t$ ime in seconds.

The bottom friction coefficient can be computed either as

$$
c_{f}=g / c^{2}
$$

in which $C$ is the Chezy discharge coefficient (foot to the one-half power per second) or as

$$
c_{f}=g n^{2} / 2.208 H^{1 / 3} \text {, }
$$


where $n$ is Manning's roughness coefficient (second per foot to the one-third power).

The effect of turbulence is modeled using Boussenesq's eddy-viscosity concept, which assumes the turbulent stresses to be proportional to the depthaveraged velocity gradients. The eddy viscosity is not a true depth-averaged quantity in a mathematical sense. Rather, this value is defined such that when multiplied by the mean-velocity gradients, the appropriate depth-averaged stress due to turbulence is obtained.

For the simulation of steady-state flow in the study reach of the Sabine River, the time-derivative terms were set to zero. In addition, the Coriolis force due to the Earth's rotation as well as wind friction also were considered negligible and set to zero. Boundary conditions for the set of equations consist of velocity components, unit-discharge components, or watersurface altitudes at open boundaries, and zero-velocity components or zero normal flow at all other boundaries.

\section{Solution Technique}

The numerical technique used to solve the governing equations is based on the Galerkin finite-element method. In this method, the two-dimensional area being modeled is divided into elements that may be either triangular or quadrangular in shape and can easily be arranged to fit complex boundaries. The elements are defined by a series of node points located at the ir vertices, midside points, and at their centers in the case of nine-node quadrilaterals. Values of the dependent variables are defined within each element in terms of the nodal values by a set of interpolation or shape functions.

Approximations of the dependent variables are substituted into the governing equations forming a residual as the equations usually are not satisfied exactly. Weighted averages of the residuals over the entire solution region are computed using numerical integration. Requiring the weighted residuals to vanish allows solution for the values of the dependent variables. In Galerkin's method, the weighting functions are chosen to be the same as those used to interpolate values of the dependent variables with in each element. Because the system of hydrodynamic flow equations is nonlinear, Newton's iterative method is used to obtain a solution.

\section{MODELING PROCEDURE}

Defining the hydraulic characteristics of a multiple-opening highway crossing of a wide floodplain is a process that varies in complexity depending on the topographic and hydraulic conditions. The procedure followed in modeling the study reach of the Sabine River includes: (1) preliminary computations, (2) collection of topographic and hydraulic data, (3) design of the finite-element network, (4) assignment of boundary conditions, (5) simulation of the proposed embankment design, (6) examination of the sensitivity of model parameters, (7) simulation of an alternate embankment design, (8) simulation of the natural condition, and (9) interpretation of the results. These steps are discussed in more detail in the following sections. 


\section{Preliminary Computations}

A one-dimensional WSPRO (water-surface profile) computation model (Shearman and others, 1986) was used to est imate the startirg downstreamboundary altitude for FESWMS. The computed water-surface profile also was used to estimate the edges of the floodplain throughout the study reach to be approximated with the two-dimensional model network. Both models were developed by the Geological Survey in cooperation with the Federal Highway Administration.

\section{Study-Reach Definition}

The study reach for WSPRO is defined by cross sections, the ir location in terms of stream length, and roughness data. Cross sections were surveyed previously by SDHPT at the downstream boundary of the study area, at a pipeline crossing about $1,500 \mathrm{ft}$ downstream from the highway, and at the upstream boundary of the study area. These cross sections approximate the natural conditions of the study area. The surveys were conducted jointly by the SDHPT and the Geological Survey.

Manning's roughness-coefficient (" $n$ ") values, used in WSPRO to compute friction losses, were estimated by SDHPT personnel and confirmed by Geological Survey personnel using on-site observations and infrared aerial photographs. The " $n$ " values vary horizontally at points in the cross section and in subareas as required by changes in the vegetal growth. Values of " $n$ " ranging from 0.080 to 0.180 were used on the floodplain and 0.035 was used in the main channel.

\section{Computed Water-Surface-Altitude Profiles}

Slope-conveyance computations were used to estimate a starting watersurface altitude because flood documentation at the downstream boundary did not exist. This computation is performed by WSPRO using values of discharge and slope specified by the user. For a discharge of $102,700 \mathrm{ft}^{3} / \mathrm{s}$ and a slope of $0.0004 \mathrm{ft} / \mathrm{ft}$, the water-surface altitude computed at the downstream boundary is about $230.5 \mathrm{ft}$.

\section{Topographic Data}

Topographic data to describe the geometry of the system include a description of the land surface and an evaluation of surface characteristics to estimate roughness coefficients. Thirty-one representative and special purpose cross-section surveys were made to define channel, floodplain, and embankment geometry to be approximated by the model network (fig. 3). Additional detailed topographic information was obtained from SDHPT. Field observations and infrared-aerial photographs of the study area were used to determine vegetation type and density in the assignment of roughness coefficients. The collected data were supplemented by Geological Survey topographic maps. 


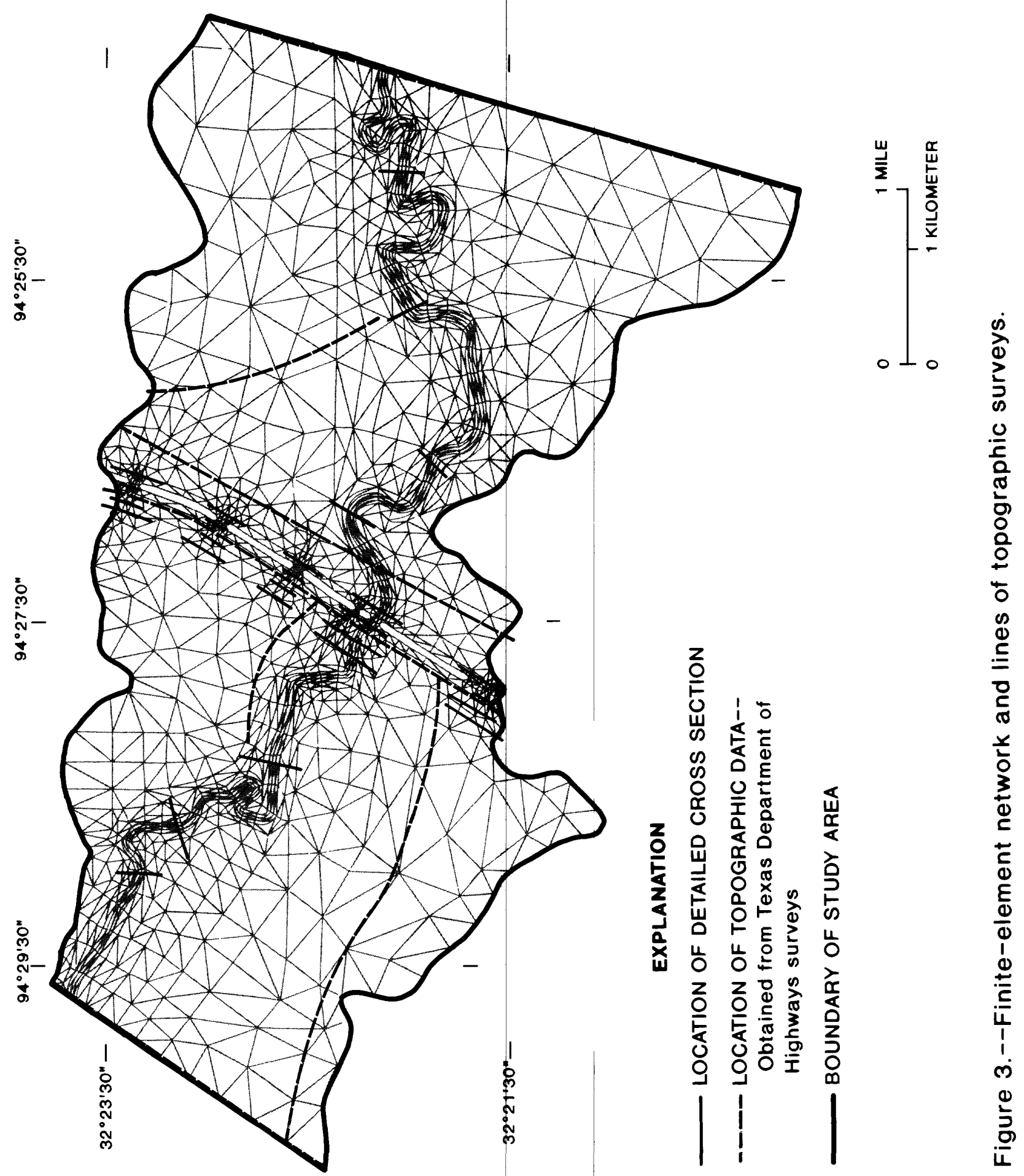




\section{Design of the Finite-Element Network}

Network design is the process of subdividing the study area into a system of elements that approximates the topography and hydraulics of the area. An element represents an area defined by the coordinates of the nodes at the corners of the triangle or quadrilateral. The basic goal of this subdivision process is to obtain a representation of the study area that will provide an adequate approximation of the true solution at a reasonable cost. This assembly of elements is referred to as the finite-element grid or finiteelement network.

The common approach to network design is to develop a level of detail slightly greater than the design scale would suggest. It is desirable to have several similar and related computed values for an area than to have only one (or no) computed values in that area. This generally will lead to a modeling network that adequately defines the area, is flexible enough to adapt easily to any alternate designs, and is numerically efficient.

The finite-element network shown in figure 3 was designed to closely represent the area expected to be inundated by the design flood based on the preliminary one-dimensional profile. The network boundaries on the left and right edges of the floodplain were located where ground-surface altitudes rise above the expected water-surface altitude. The upstream (inflow) and downstream (outflow) boundaries are located upstream and downstream of the crossing at a distance greater than the width of the floodplain. The primary purpose of locating flow boundaries an appreciable distance from the highway crossing is to minimize the effect of any errors in boundary specifications on the values computed at the highway crossing. Equally important in locating upstream and downstream boundaries an appreciable distance from the crossing is to ensure that modifications to the highway crossing have little effect on the upstream- or downstream-boundary conditions.

After the boundaries were defined, the study area was divided into a network of triangular elements. Each element was designed to represent an area of nearly homogeneous vegetative cover. In areas where the direction of flow is known, elements were elongated by a length to width ratio of 8 or less. When changing the level of detail within the network, the ratio of the area of adjacent elements was kept to less than 2 in most cases. Each node at the element vertices was specified by the appropriate $x$ and $y$ coordinates and ground-surface altitude. In areas where velocity, depth, or water-surface gradients were expected to be large, such as near bridge openings and in areas between overbanks and channel bottoms, network detail was increased to facilitate simulation of the larger gradients by the flow model. The complex geometry of the major features in the floodplain of the Sabine River was defined in detail, and prototype lengths and widths were represented realistically.

\section{Steady-State Approximation}

There is not sufficient flood record to quantitatively evaluate the state of flow that could be expected for a flood of the 50-year magnitude. In genera1, a steady-state approximation is considered to provide sufficiently accurate computations for many bridge design purposes. This assumption provides simplication of the computational effort and, when appropriately 
applied, does not significantly reduce model reliability. In the case of this analysis, an unsteady flow computation would not be economically feasible given the size and resolution of the nodal network.

\section{Boundary Conditions}

Boundary conditions specified for the network are considered either as open boundaries or solid boundaries. Open boundaries may be specified in the form of water-surface altitude, velocity, or unit discharge at a node. Solid boundaries are specified as slip (tangential flow) or no-slip (zero flow). The left and right edges of the floodplain as well as the faces of the embankment are considered solid boundaries. All solid boundaries in this study are specified as slip boundaries. The upstream (inflow) and downstream (outflow) boundaries are defined as open boundaries.

At the upstream boundary, unit discharge was specified at each node to distribute flow across the floodplain in such a way as to result in a computed lateral water-surface slope that is approximately zero at the boundary. Unit discharge is defined as the velocity times the depth at a point. It is convenient to think of unit discharge in terms of discharge per foot of width.

The downstream boundary was specified as a water-surface altitude. The water-surface altitude specified is constant across the boundary, resulting in a computed lateral water-surface slope that is approximately zero at the downstream boundary. The determination of the most appropriate downstreamboundary altitude was based on computations of water-surface altitude using one-dimensional procedures. The altitude was determined to be $231 \mathrm{ft}$ and was used as the downstream boundary for the two-dimensional simulations. In the vicinity of the downstream boundary, several nodes have an altitude between 230 and $231 \mathrm{ft}$. The model allows nodes to become dry and consequent ly become a boundary. However, the ability to accurately use this feature requires a greater level of detail in the network for those locations. The approximation of the system represented as the finite-element network (fig. 3) does not have a level of detail fine enough to allow elements to become dry near the downstream boundary and still adequately define the general geometry of the floodplain. The effects of a different boundary specification on the watersurface altitudes computed at the highway crossing can be evaluated through sensitivity analysis, discussed in sections to follow.

\section{WATER SURFACE AND FLOW DISTRIBUTION}

The proposed highway-crossing design was simulated using the values of Manning's roughness coefficient (" $n$ ") shown in table 3, a base eddy viscosity of 20 , a discharge of $102,700 \mathrm{ft}^{3} / \mathrm{s}$, and a downstream aititude of $231.0 \mathrm{ft}$. In discussions to follow, this simulation will be referred to as the proposed simulation. Before a simulation for the desired boundary conditions can be performed, some "warm-up" type simulations are required. 
Table 3.--Values of Manning's roughness coefficient (" $n$ ") used in the proposed design

\begin{tabular}{ll}
\hline Location & $\begin{array}{l}\text { Manning's roughness } \\
\text { coefficient ("n") }\end{array}$ \\
\hline
\end{tabular}

Floodplain area

Main channel

At bridge openings, with in the right-of-way
$0.140-0.120$

$.035-.030$

$.040-.035$

1 The two values shown are those used for different depths as specified with the roughness coefficients. The smaller of the two values is used for the deeper areas.

For the first iteration in the process of solving the flow equations, all nodes are assigned values of depth which correspond to a water-surface altitude that is equal for all nodes in the network. All boundary conditions remain the same during the simulation with the exception of the downstream water-surface-altitude specification, which is reduced in increments during "warm-up" iterations until a simulation at the desired final-altitude specification has converged.

The discharge computed through each structure by FESWMS and that apportioned by the SDHPT is given in table 4 . For any structure, the difference between the two models in distributing the total discharge is within 6 percent of the total discharge. The largest difference occurred at the main channel opening.

Table 4.--Computed distribution of discharge among bridge openings for one- and two-dimensional analyses of the proposed design

\begin{tabular}{lcc}
\hline \multicolumn{1}{c}{ Opening } & $\begin{array}{c}\text { One-dimensional } \\
\text { analys is flow } \\
\text { (percent) }\end{array}$ & $\begin{array}{c}\text { Two-dimensiona } \\
\text { analys is flow } \\
\text { (percent) }\end{array}$ \\
\hline Right overf low & 14 & 11 \\
Main channel & 41 & 35 \\
Oxbow overf low & 6 & 9 \\
First left overflow & 12 & 14 \\
Second left overf low & 14 & 16 \\
Third left overflow & 13 & 15 \\
\hline
\end{tabular}

1 One-dimensional flow is as determined in proposed crossingdesign analysis by the Texas State Department of Highways and Public Transportation.

2 Two-dimensional flow is as determined in two-dimensional analys is by the U.S. Geological Survey.

The fall through each opening of the proposed embankment is equal to 0.26 $\mathrm{ft}$ for the one-dimensional technique (WSPRO) using the floodplain defined from 
a cross section $36 \mathrm{ft}$ upstream from the existing roadway. The fall computed from the two-dimensional technique (FESWMS) was based on computed watersurface altitudes at nodes at the upstream and downstream edges of the opening. The two-dimensional-model computations reflect larger values of fall for all the openings except the right overflow (table 5). The important point in comparing the results is not necessarily that the computed fall is larger, but that the difference in fall is not consistent for all the openings. In fact, the computed value from the two-dimensional analys is for the right opening is significantly smaller than all other values. The computed watersurface altitude for the proposed highway embankment is represented in the form of contours in figure 4 . The value for the depth-averaged velocity at node points within the bridge openings are shown in figure 5 . Unit discharge at node points within the bridge openings are shown in figure 6 .

Table 5.--Computed fall through bridge openings for the proposed bridge design for one- and two-dimensional analyses

\begin{tabular}{lcc}
\hline \multicolumn{1}{c}{ Opening } & $\begin{array}{c}\text { One-dimensional } \\
\text { analysis fall } \\
\text { (foot) }\end{array}$ & $\begin{array}{c}\text { Two-dimensiona } \\
\text { analysis fal1 } \\
\text { (foot) }\end{array}$ \\
\hline Right overf low & 0.26 & 0.02 \\
Main channe 1 & .26 & .42 \\
0xbow overf low & .26 & .46 \\
First left overf low & .26 & .33 \\
Second left overf low & .26 & .52 \\
Third left overf low & .26 & .50 \\
\hline
\end{tabular}

Water-surface contours near the upstream and downstream boundaries are generally perpendicular to the axis of the floodplain (fig. 4) indicating no lateral flow. This is to be expected for the conditions specified at the boundaries. Nearly one-dimensional flow is simulated at these boundaries. The contours near the highway crossing are skewed somewhat from the perpendicular of the axis of the floodplain, and this skewness is an indication of lateral flow. On the upstream side of the highway crossing, a water-surface altitude of about $238.7 \mathrm{ft}$ is computed at the right edge of the floodplain, whereas an altitude of about $237.3 \mathrm{ft}$ is computed at the left edge of the floodplain. This lateral water-surface slope indicates a redistribution of flow across the floodplain.

Examination of figure 5 shows that the greatest computed velocities of about $6 \mathrm{ft} / \mathrm{s}$ occur at the center of the main channel and oxbow openings. The largest computed velocities in the left overflow openings range from 2 to about $4 \mathrm{ft} / \mathrm{s}$. The right overflow has computed velocities of less than 1.5 $\mathrm{ft} / \mathrm{s}$.

Unit discharge is the product of the velocity and depth at a node. It can be considered a measure of discharge per foot of width. The right overflow is the least productive per foot of width of all the openings having computed values of unit discharge under $20\left(\mathrm{ft}^{3} / \mathrm{s}\right) / \mathrm{ft}$ throughout the opening (fig. 6). The main and oxbow channels have the largest values of unit 


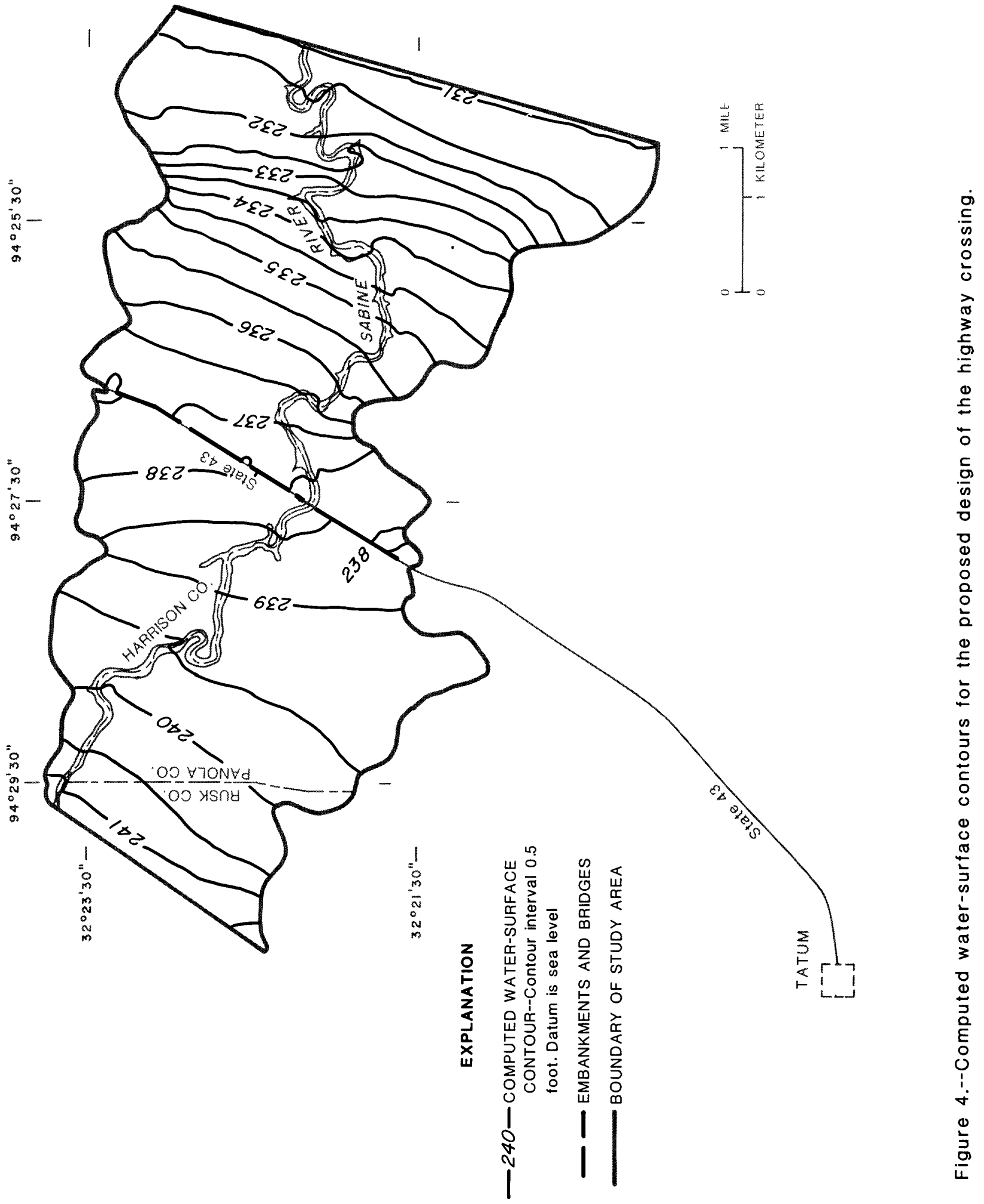




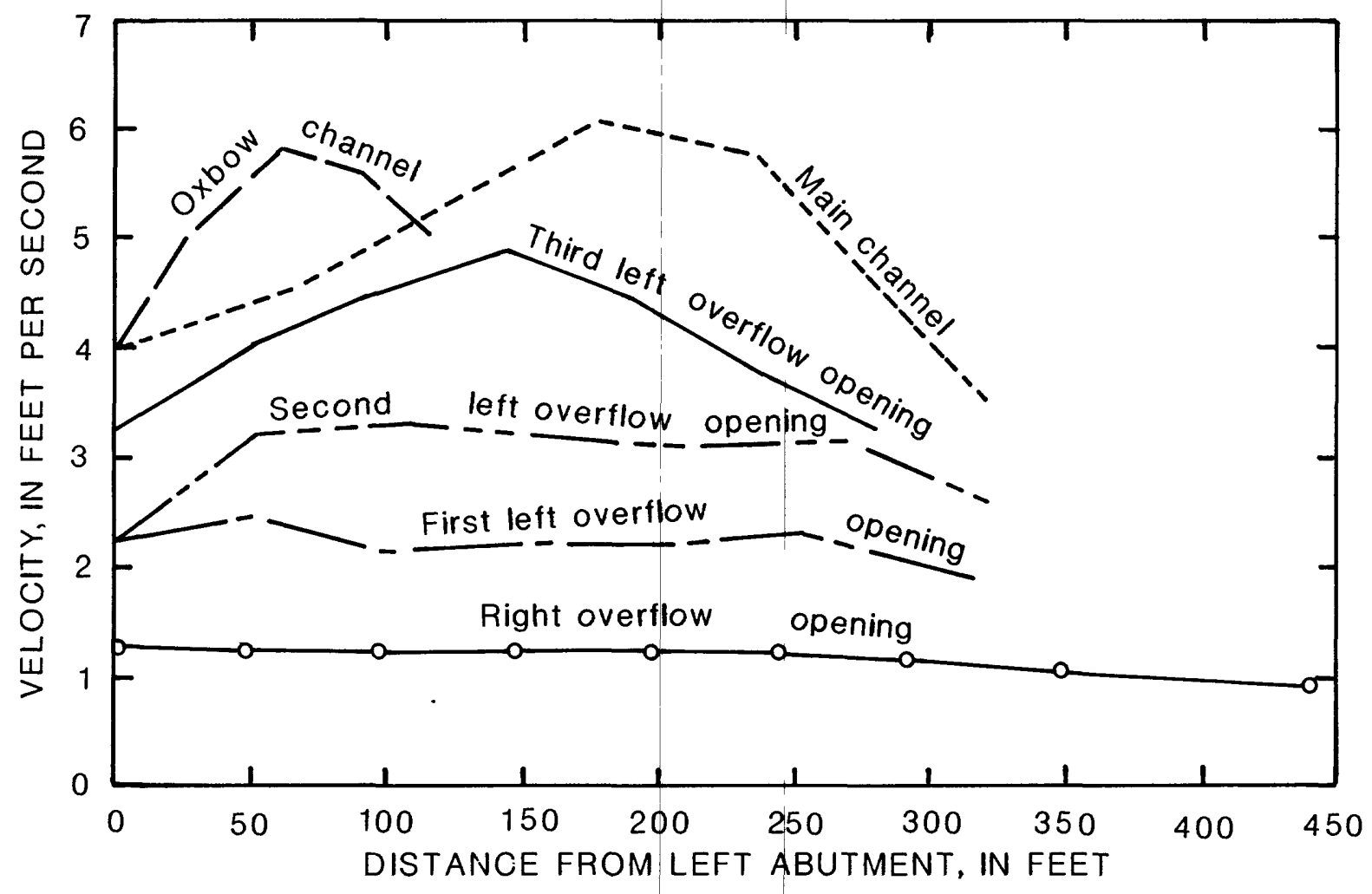

Figure 5,--Computed velocities within the bridge openings for the proposed design. 


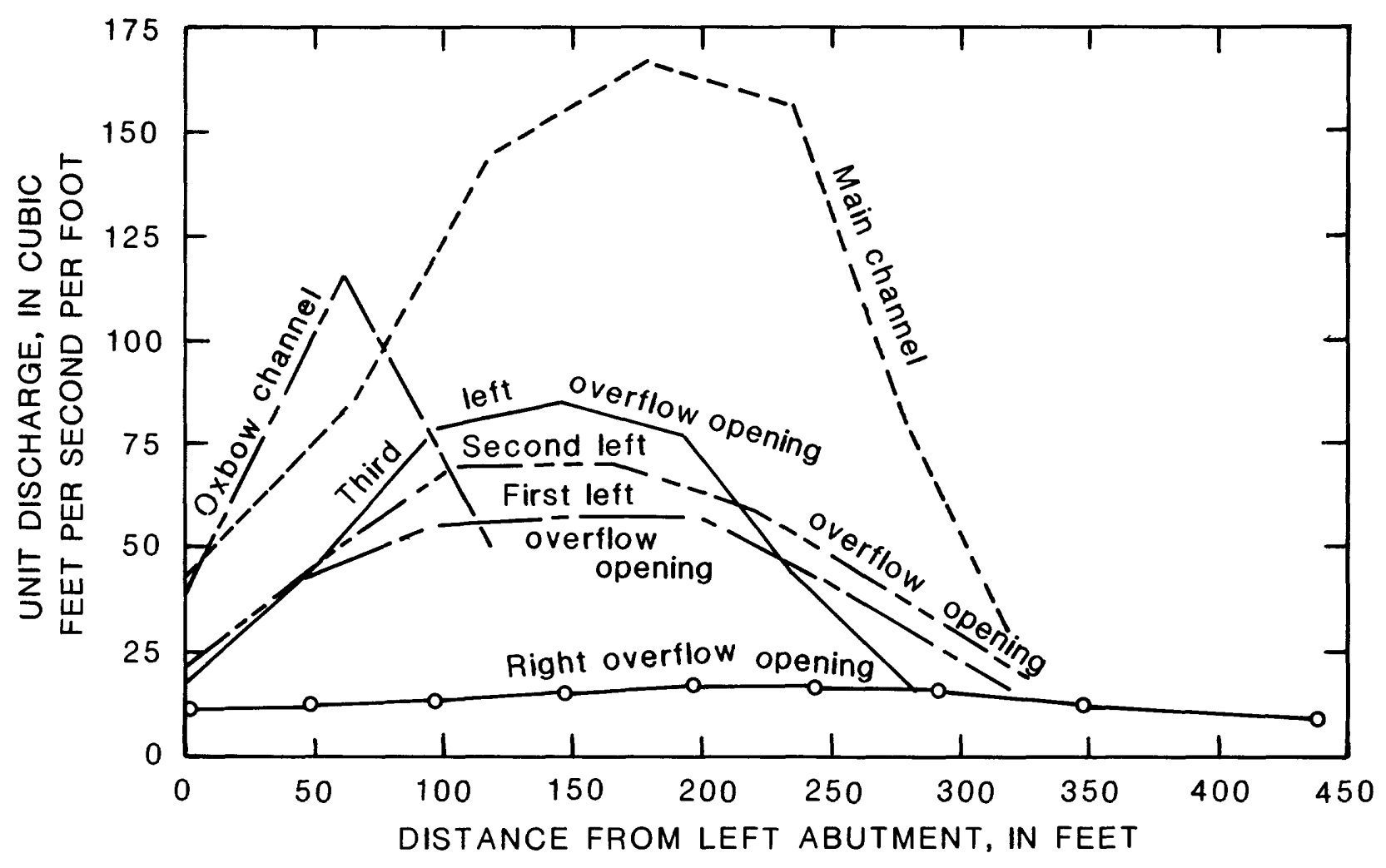

Figure 6.--Computed unit discharge within the bridge openings for the proposed design. 
discharge, ranging from 30 to $170\left(\mathrm{ft}^{3} / \mathrm{s}\right) / \mathrm{ft}$. All three remaining left overflow bridges perform similarly with computed values of unit discharge ranging from about 20 to about $75\left(\mathrm{ft}^{3} / \mathrm{s}\right) / \mathrm{ft}$ as shown in figure 6 .

Four possible causes for this lateral flow and relative inefficiency of the right overflow are believed to be: (1) the design of the bridge openings at the highway crossing, (2) the lateral ground-surface variations in the vicinity of the highway crossing, (3) some geometric or hydraulic feature downstream from the highway crossing, or (4) some combination of the above.

\section{SENSITIVITY ANALYSIS}

The process of sensitivity analys is is the comparison of the results of two simulations, each having a 11 but one of the input parameters identical. A simulation using an alternate value of a parameter is then compared to the simulation using the initial value of the parameter. The difference in the results is the effect of changes in that parameter and is an indicator of the sensitivity of that parameter to the solution. A magnitude of change in any parameter was chosen to be about 15 percent for two reasons: (1) to keep the relative change in the parameters approximately equal among the sensitivity analyses, and (2) to compare results that are based on values that commonly have some meaning to the hydraulic analyst. As examples of the second reasoning, changes in the values of the Manning's roughness coefficient (" $n$ ") from 0.14 to 0.12 or from 0.040 to 0.035 are changes of about 15 percent in the magnitude of the coefficient. A change of $0.5 \mathrm{ft}$ in the water-surfacealtitude specification at the downstream boundary is about a 15-percent change in depth of flow in the floodplain.

\section{FESWMS (Finite-Element Surface-Water Modeling System) Model}

For the simulations using FESWMS, the tested parameters were the downstream-boundary specification of water-surface altitudes, Manning's roughness coefficient (" $n$ "), the upstream-boundary specification of discharge, and the base eddy-viscosity coefficient. The finite-element network used for all simulations was the same as for the proposed design simulation.

\section{Downstream-Boundary Specification}

Simulations were performed with downstream-boundary conditions that were 0.5 and $1.0 \mathrm{ft}$ higher and lower than the initial-boundary condition of 231.0 $\mathrm{ft}$. A 0.5-ft change is approximately equal to a 15-percent change in depth in the floodplain at the downstream boundary. All specifications of Manning's roughness coefficient (" $n$ "), discharge, and eddy viscosity rema in the same as those in the initial simulation. For changes of 0.5 and $1.0 \mathrm{ft}$ below the initial-boundary specification of $231.0 \mathrm{ft}$, the response of the model was nearly identical in magnitude but opposite in sign for changes of 0.5 and 1.0 $\mathrm{ft}$ above the initial-boundary specification. A change of $1.0 \mathrm{ft}$ in the initial downstream-boundary specification results in a corresponding change of about $0.1 \mathrm{ft}$ at the left bank of the highway crossing (fig. 7 ). 


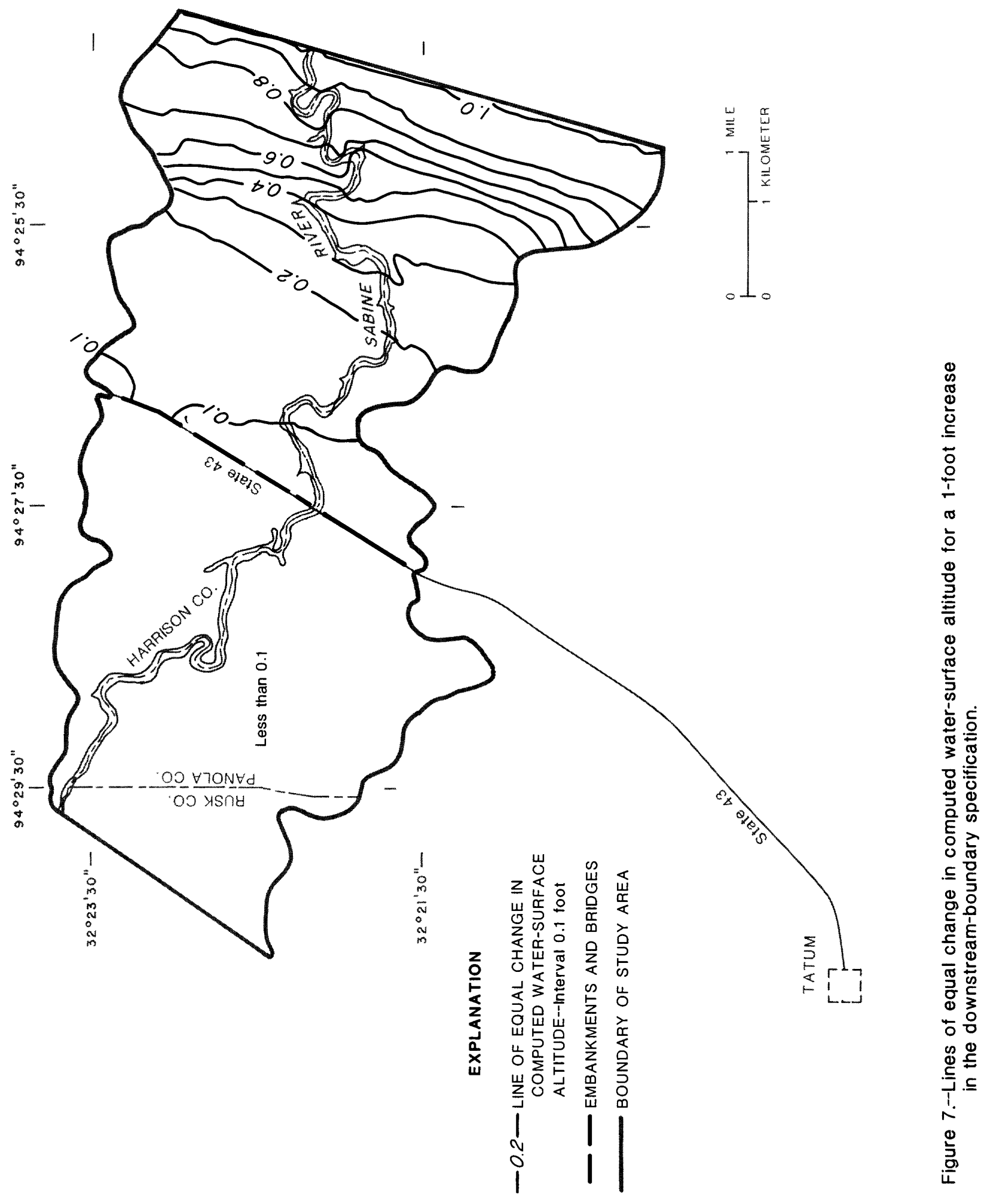


Manning's Roughness Coefficient ("n") Value

Manning's roughness coefficient (" $n$ ") value is used to compute friction losses in the stream system. The sensitivity of this parameter was evaluated by modifying " $n$ " value specifications by about 15 percent and comparing test results to the initial results. A 15-percent variability in " $n$ " values is a reasonable measure of the variability involved when choosing the values. A change in " $n$ " from 0.14 to 0.12 or from 0.040 to 0.035 represents a change of about 15 percent.

Al1 specifications of discharge, downstream-boundary specification, and base eddy viscosity remained the same as those for the proposed design simulation. Values of " $n$ " were varied at several locations as follows: (1) throughout the entire network, (2) only in the floodplain, (3) only in the main channel, and (4) only within the embankment openings.

The water-surface altitudes computed for these conditions can be compared with the proposed design simulation to determine the effects on the solution results. Comparison of the computed water-surface altitudes for the " $n$ " values used in the proposed design and modified " $n$ " values and selected simulators are shown in figures 8 and 9.

For a 15-percent change of " $n$ " throughout the study reach, computed values of water-surface altitude change by about $0.7 \mathrm{ft}$ in the vicinity of the highway crossing as shown in figure 8. For a 15-percent change in " $n$ " in the floodplain areas only, computed values of water-surface altitude change by slighty less than $0.7 \mathrm{ft}$ at the embankment on the right bank, as shown in figure 9. An examination of these results indicate that the model is more sensitive to floodplain roughness than to roughness in the channel and bridge openings. This supports the hypothesis that floodplain roughness controls the friction losses because the majority of flow is over floodplain areas except at the embankment.

\section{Discharge}

The sensitivity of the model to changes in discharge was evaluated by two simulations: (1) a discharge of $118,100 \mathrm{ft}^{3} / \mathrm{s}$ (15 percent greater than the design flood) and (2) a discharge of $87,300 \mathrm{ft}^{3} / \mathrm{s}$ (15 percent less than the design flood). All values of downstream-boundary specification, Manning's roughness coefficient (" $n$ "), and base eddy viscosity remained the same as for the proposed simulation. For an increase in discharge, computed water-surface altitudes rose throughout the study area. For a decrease in discharge, the changes in water-surface altitudes were approximately the same in magnitude but opposite in sign as the test for an increase in discharge. Some minor exceptions to this generalization may be due to the change in the floodplain response from the changes in depths of flow. In general, a 15-percent change in total discharge changes the water-surface altitudes by about $0.8 \mathrm{ft}$ at the highway crossing (fig. 10).

\section{Base Eddy Viscosity}

The eddy-viscosity coefficient is a parameter used in the computation of energy losses in the system due to turbulence. Generally, higher values of 


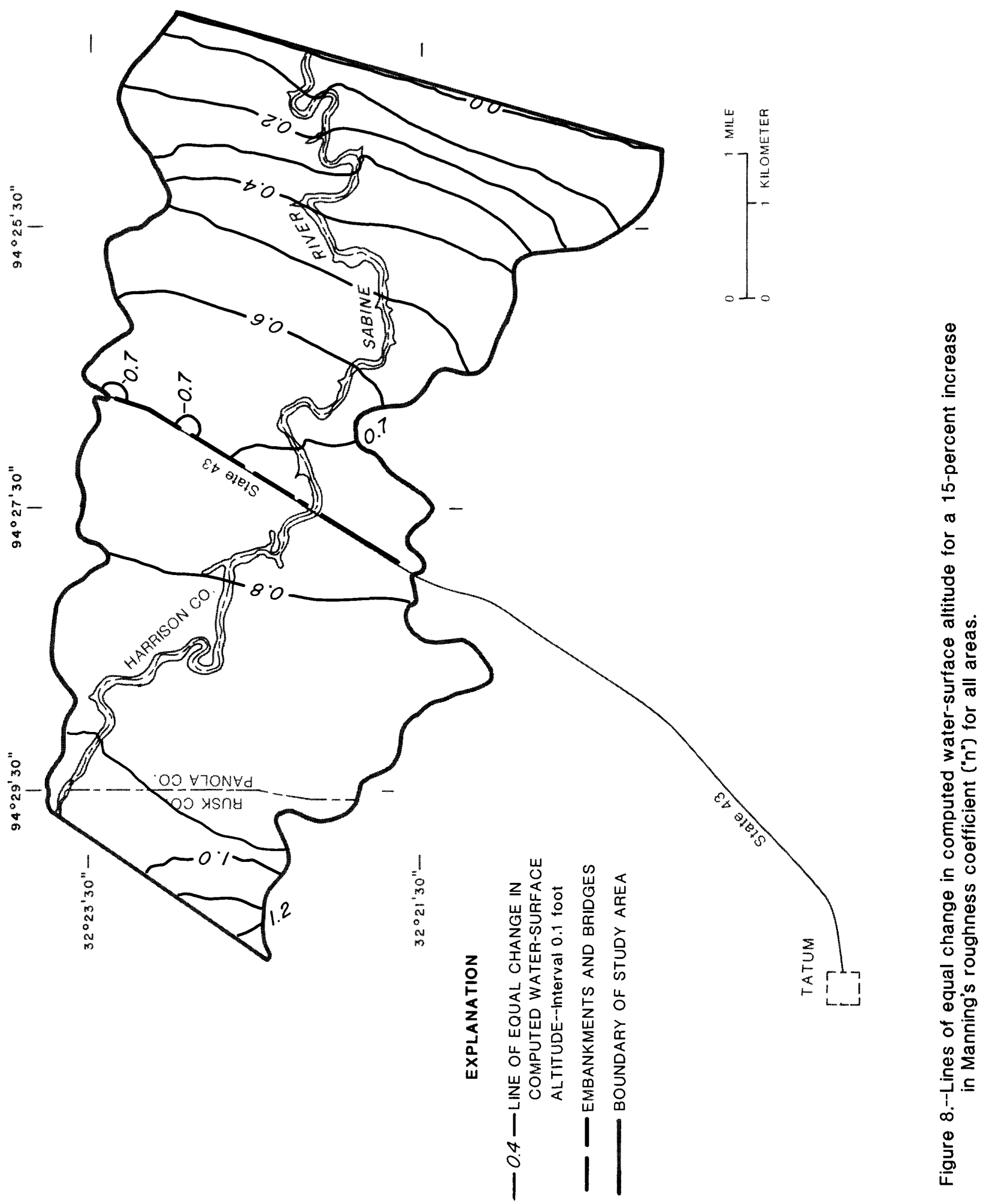




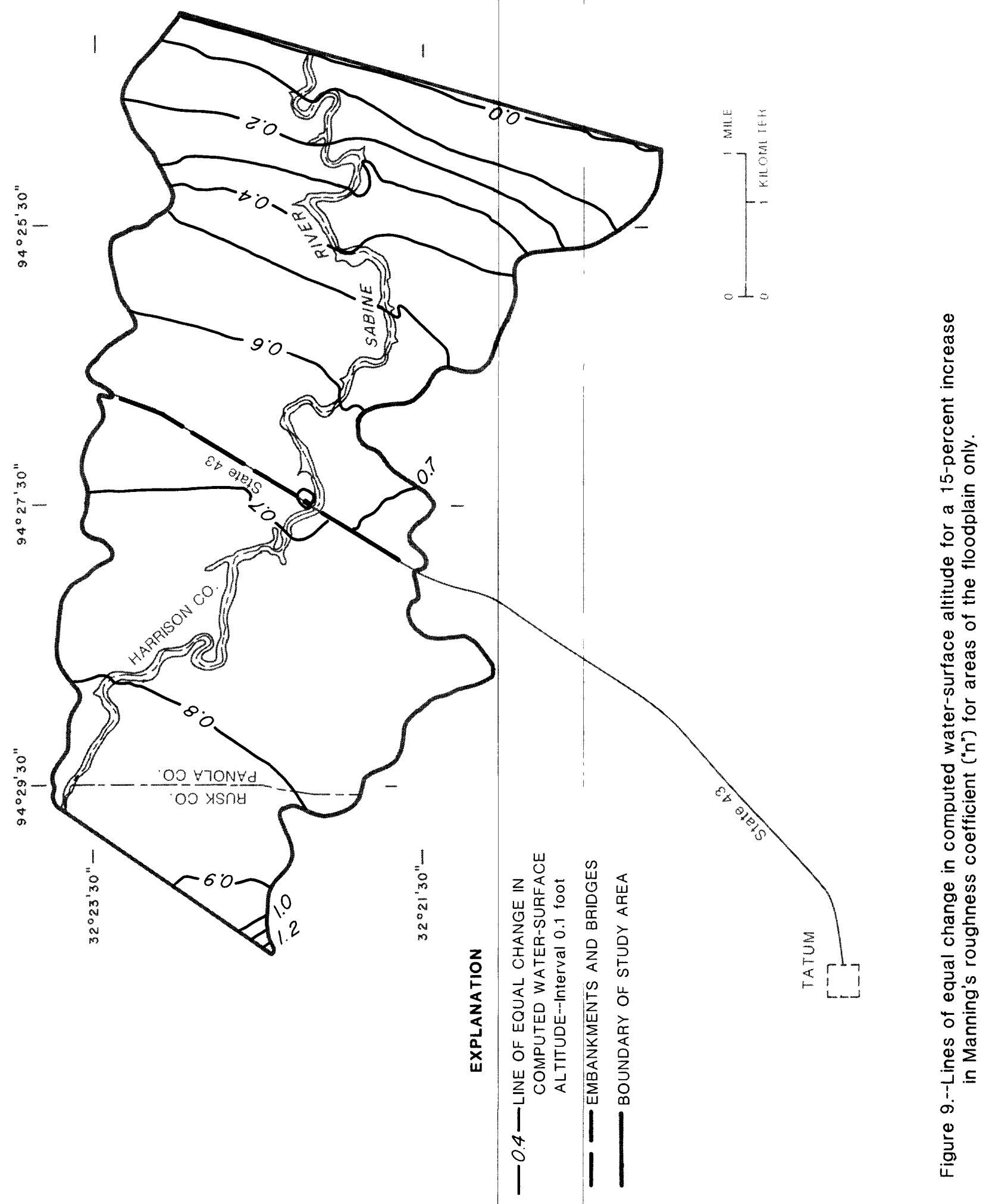




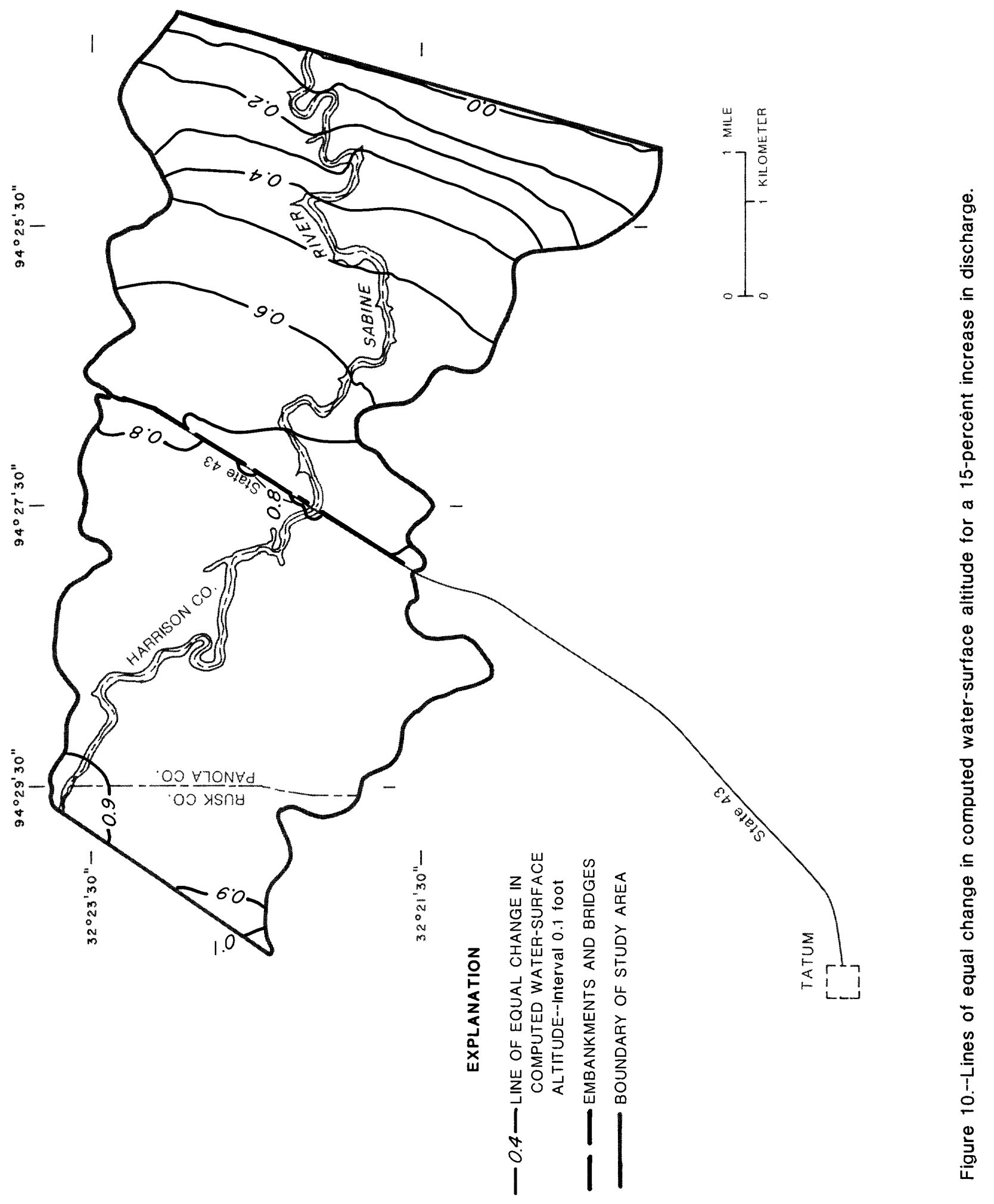


eddy viscosity tend to increase numerical stability, but may also overestimate the turbulent losses in the system. The selected procedure was to use a value large enough to ensure convergence during the "warm-up" simulations and then to decrease to a value as small as possible without introducing numerical instability during the final simulations. This minimizes any effect of over-estimation of energy losses due to turbulence and still provides a model with sufficient numerical stability to converge to an approximation of the true solution.

The model has the capability to vary the eddy-viscosity coefficient proportionately with depth and velocity. This feature is used by specifying a base eddy-viscosity coefficient and allowing the model to adjust it at each node by an amount that is proportional to the depth and velocity.

The sensitivity of this parameter was evaluated by comparing simulation results using base eddy-viscosity values ranging from 20 to $150 \mathrm{ft}^{2} / \mathrm{s}$. For al1 of the simulations (base values of $150,75,50,30$, and $20 \mathrm{ft}^{2} / \mathrm{s}$ ), reductions in base eddy viscosity resulted in a lowering in water-surface altitudes. For a change in eddy viscosity from 150 to $20 \mathrm{ft}^{2} / \mathrm{s}$, water-surface altitudes are lowered by about $0.4 \mathrm{ft}$ in the vicinity of the embankment (fig. 11). For a change from 50 to $20 \mathrm{ft}^{2} / \mathrm{s}$, water-surface altitudes are lowered about $0.1 \mathrm{ft}$ in the vicinity of the embankment (fig. 12). The use of a base value less than $20 \mathrm{ft}^{2} / \mathrm{s}$ tended to introduce numerical instability. Considering that the use of a value of $20 \mathrm{ft}^{2} / \mathrm{s}$ produced water-surface a 1titudes less than $0.1 \mathrm{ft}$ lower than the altitudes produced by a value of 50 $\mathrm{ft}^{2} / \mathrm{s}$ (a 150-percent increase), additional reductions in the value of the base eddy viscosity below $20 \mathrm{ft}^{2} / \mathrm{s}$ would not significantly lower the computed water-surface altitudes.

\section{WSPRO (Water-Surface Profile) Mode1}

Having gained some indications of the sensitivity of the two-dimensional mode1, it is beneficial to know some of the sensitivities of the onedimensional model used for preliminary computations. A sensitivity analys is of WSPRO was made for the parameters of the downstream boundary, Manning's roughness coefficient (" $n$ "), and discharge.

Several water-surface profiles were computed using starting water-surface altitudes of 0.5 and $1.0 \mathrm{ft}$ higher and lower than the base a t itude of 231.0 $\mathrm{ft}$. Values of " $n$ " and discharge remained unchanged. The water-surface a 1titudes computed for changes in starting water-surface altitudes are shown in figure 13. A 1.0-ft higher starting water-surface altitude results in a rise of less than $0.2 \mathrm{ft}$ at the location of the highway crossing. For values of starting water-surface altitudes lower than the base flow, the change in computed water-surface altitudes is essentially the same in magnitude, but opposite in sign, as for higher starting water-surface altitudes. This is an indication that computed values at the location of the highway crossing are not sensitive to changes in the starting water-surface altitude specified at the downstream boundary.

A graph of water-surface altitude comparing distance along the study reach for the proposed " $n$ " values and a 15-percent increase and decrease in the " $n$ " values is shown in figure 14. A 15-percent change in the " $n$ " value caused about a $0.7-\mathrm{ft}$ change in water-surface altitude in the center of the 


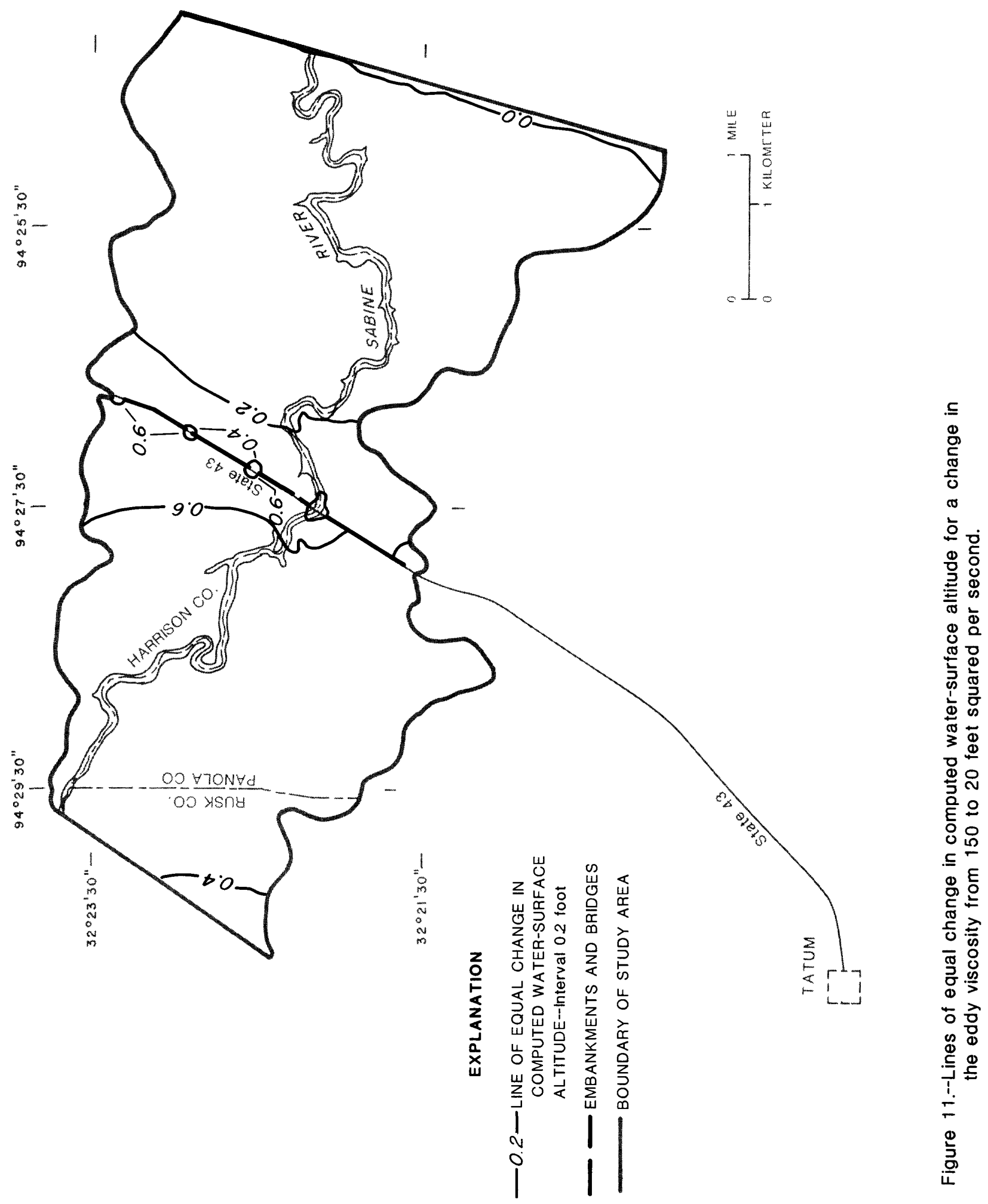




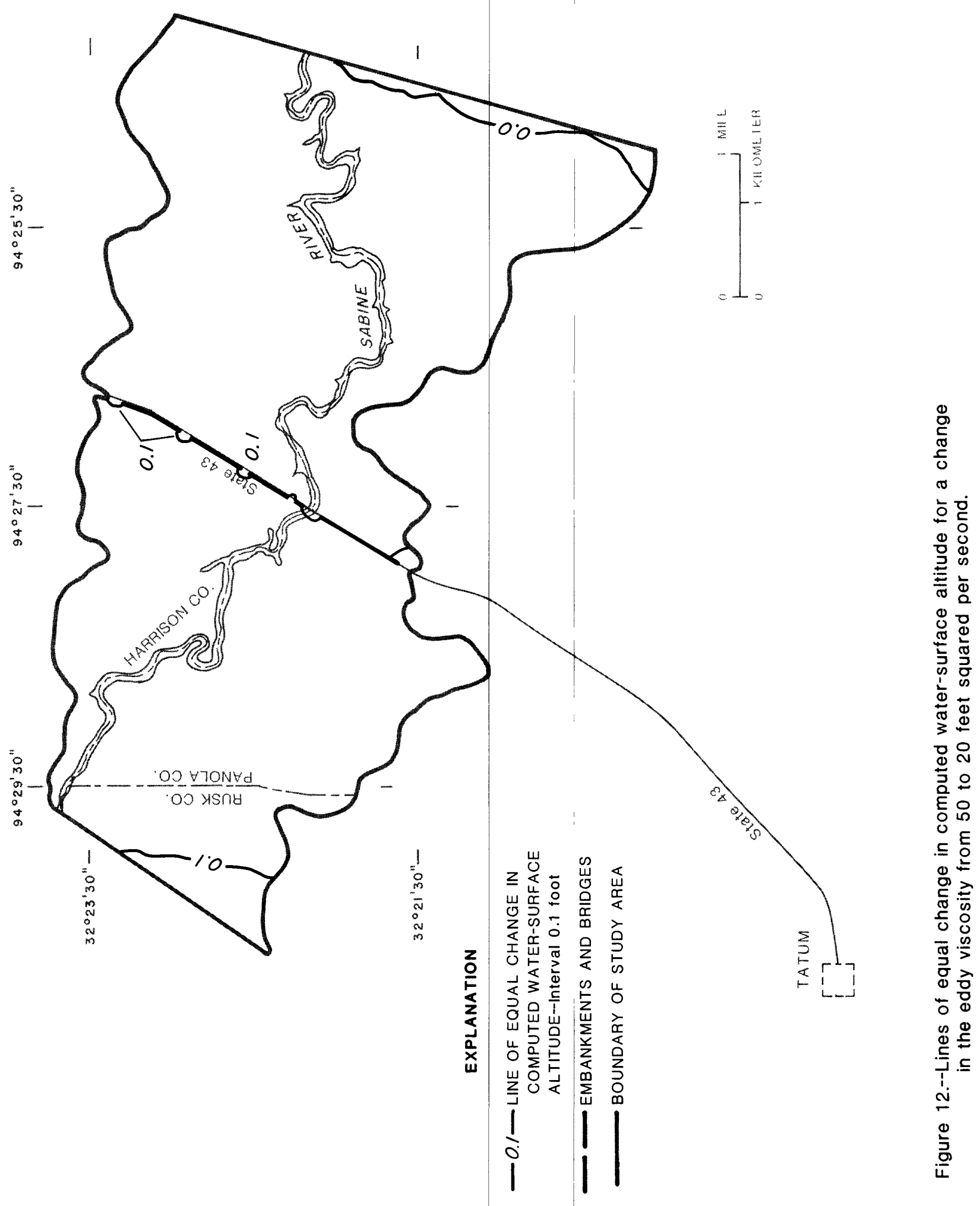




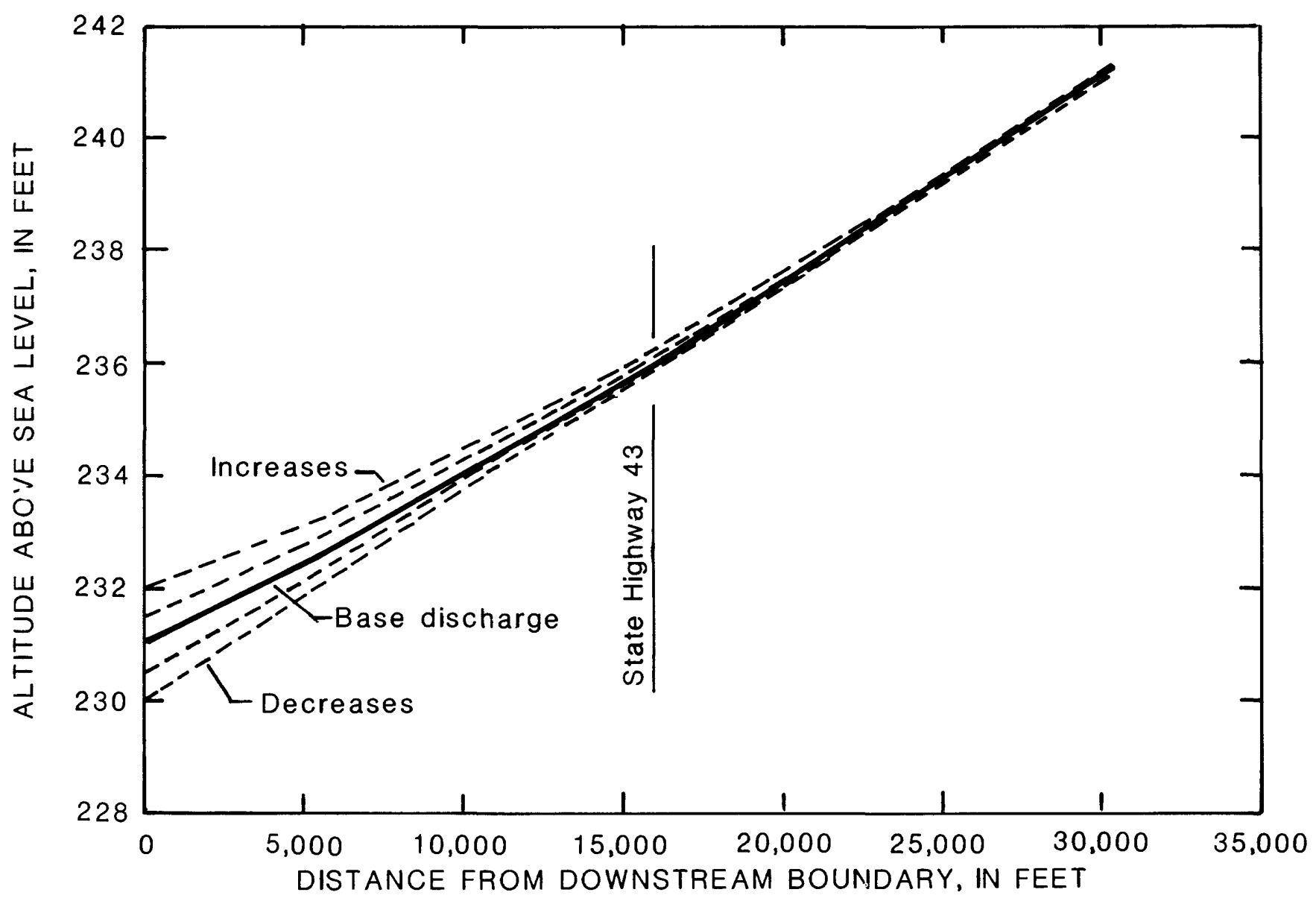

Figure 13,--Water-surface profiles computed using the WSPRO (water-surface profile) model with different starting water-surface altitudes at the downstream boundary. 


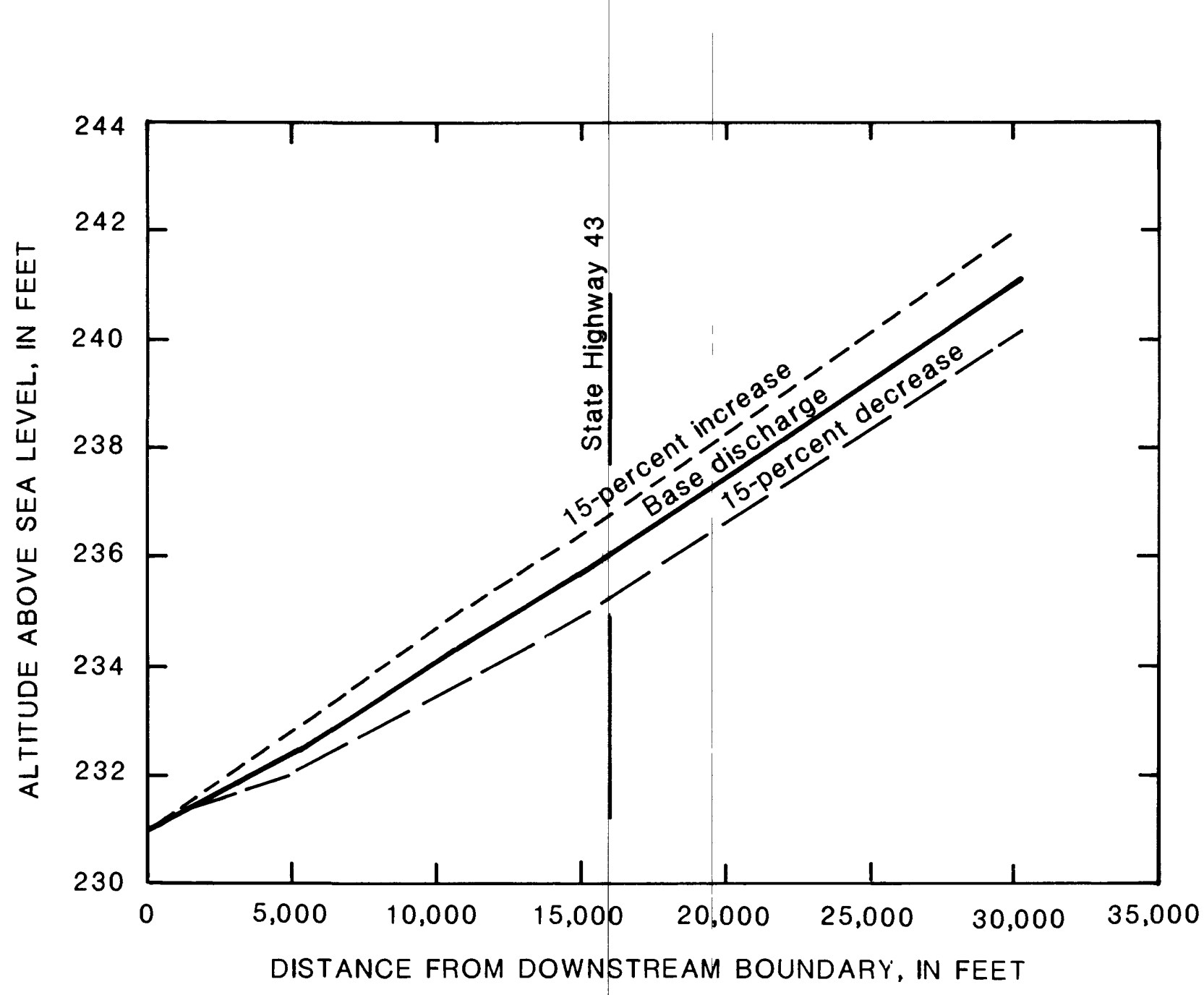

Figure 14.--Water-surface profiles computed using the WSPRO (water-surface profile) model with a 15-percent change in Manning's roughness coefficient (" $n$ "). 
study area, where the bridges and highway embankments are located (fig. 14), and about a 1.0-ft change at the upstream boundary. This is an indication that the model is sensitive to changes in the " $n$ " values. Consequently, the values selected must be representative and consistent throughout the study area for simulated water-surface altitudes to be reliable.

Water-surface altitudes that result from a 15-percent increase or decrease in discharge are shown in figure 15. A 15-percent change from the initial discharge will cause a change of about $0.7 \mathrm{ft}$ in altitude near the highway crossing and a change of about $0.9 \mathrm{ft}$ at the upstream boundary. This indicates that the model also is sensitive to changes in discharge.

\section{SIMULATION OF ALTERNATE DESIGN}

After examination of preliminary results and discussion with the SDHPT, simulation of an alternate design proposed by SDHPT was performed. As previously mentioned, the right overflow conveyed the least amount of discharge per unit width of the openings, whereas the main and oxbow channel openings conveyed the greatest discharge per foot of width. Based on this, the alternate design: (1) eliminates some of the proposed embankment between the main channel and oxbow overflow openings, and (2) reduces the width of the right overflow to $200 \mathrm{ft}$. This alternate design closely resembles the existing bridge widths, differing only in the increase in widths at the second and third left overflow bridges (table 1 ).

\section{Network Modification}

The finite-element network for the alternate design was created by adding elements to represent modification of the embankment at the ma in channel opening and removing some elements at the right overflow. The alternate design was simulated using the same geometric and boundary data as the proposed embankment design with the exception of the geometric changes of the embankment.

\section{Results of the Simulation}

The computed water-surface contours for the alternate simulation are shown in figure 16. Computed water-surface contours are nearly identical to the proposed simulation. Water-surface lowering for the area upstream from the crossing was less than $0.1 \mathrm{ft}$ at the edges of the floodplain. A lowering of less than $0.1 \mathrm{ft}$ also was computed for the area immediately downstream from the right overflow bridge. There are rises of less than $0.1 \mathrm{ft}$ in the watersurface altitude in the areas immediately downstream from the main channel opening and immediately upstream from the right overflow.

\section{SIMULATION OF NATURAL CONDITIONS}

The condition simulated without the embankment is considered to represent the hydraulics of the study area under natural conditions. Computations of any highway-crossing design can be compared to the results of this simulation to establish the overall effects. 


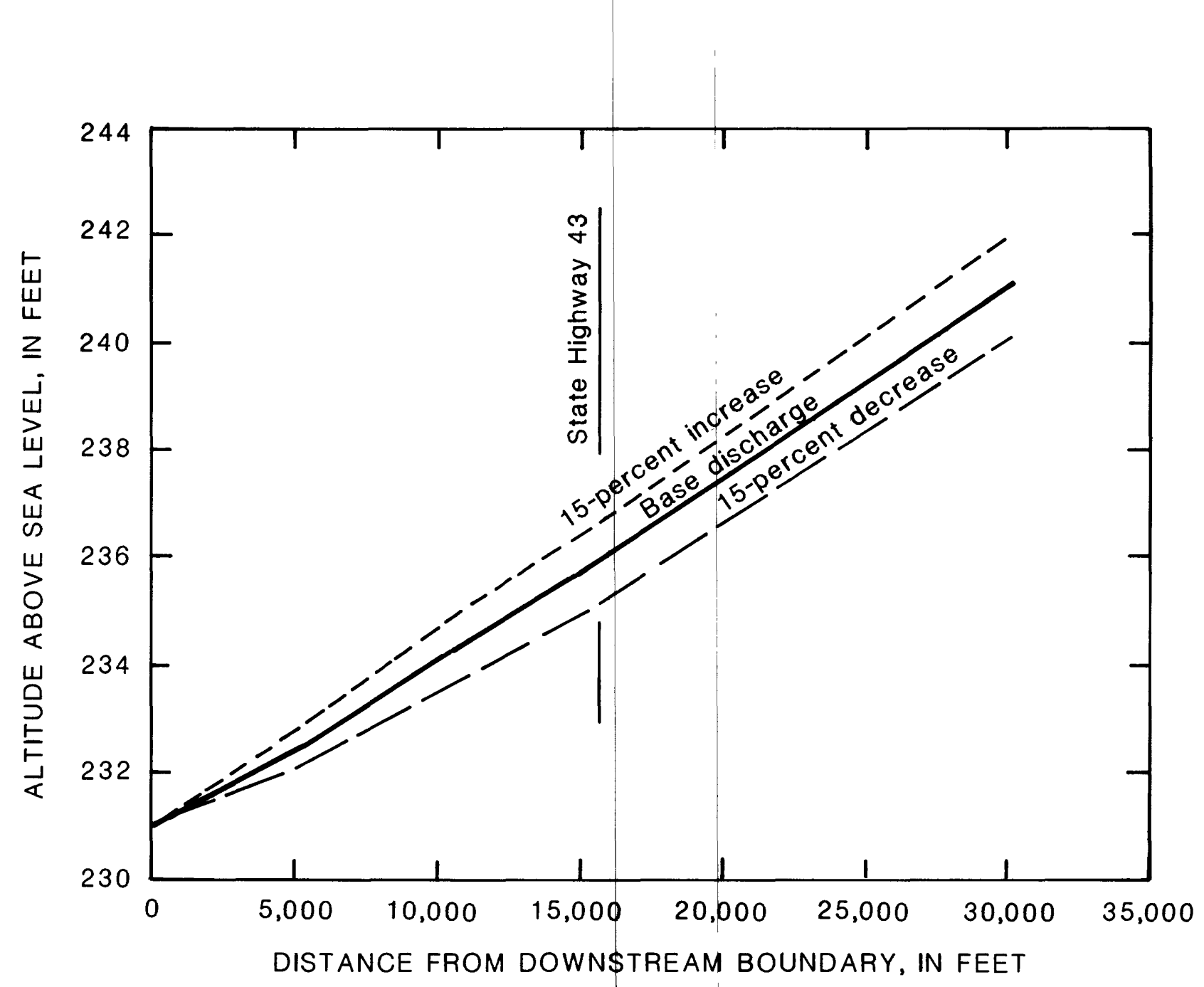

Figure 15.--Water-surface profiles computed using the WSPRO (water-surface profile) model with a 15-percent change in discharge. 


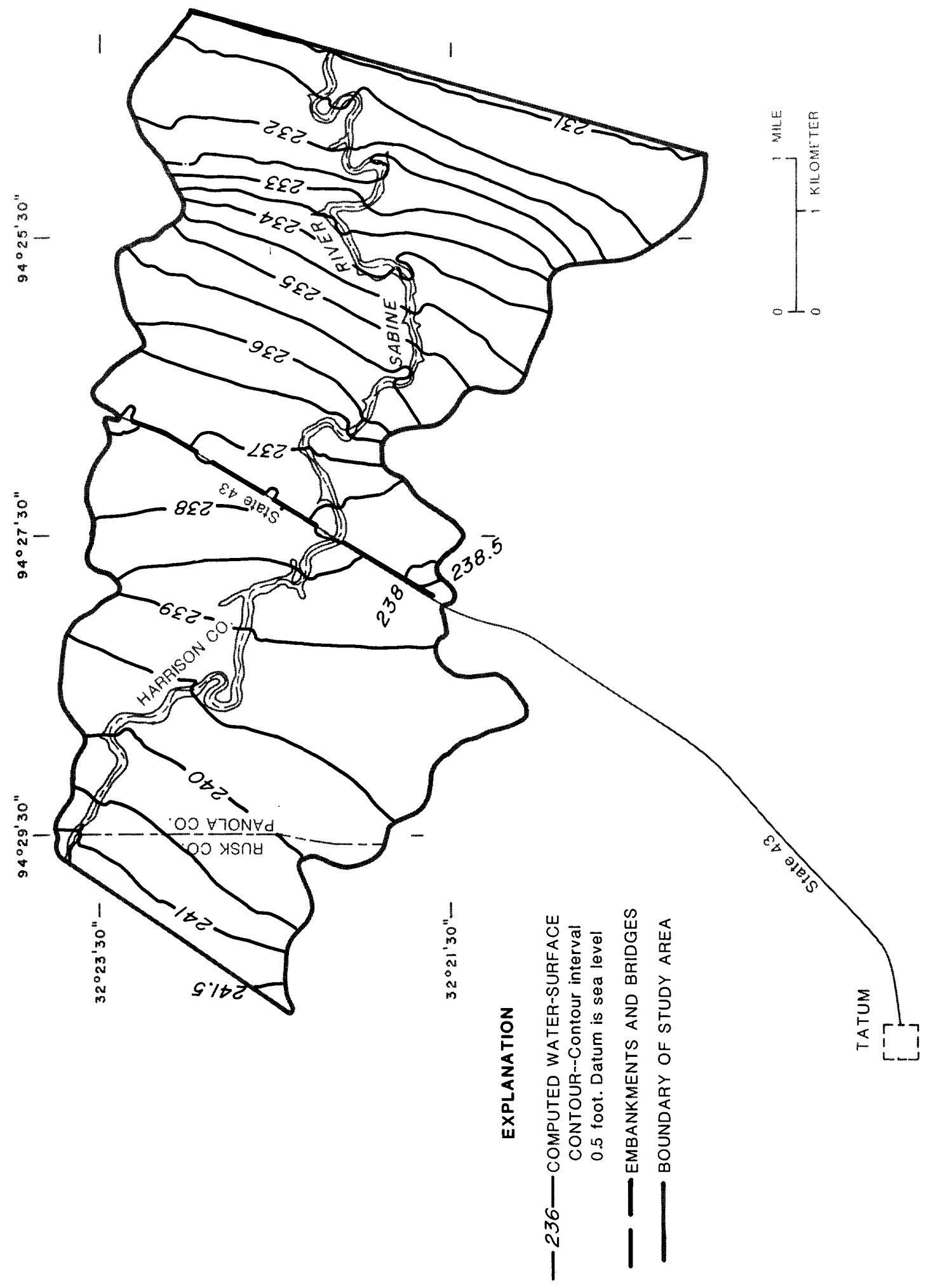

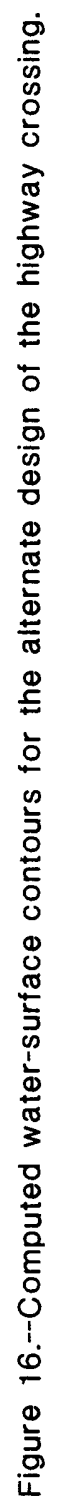




\section{Network Modification}

The simulation without the embankment was performed by adding elements in all the highway-embankment areas. The added elements were assigned Manning's roughness coefficient (" $n$ ") values equal to those of the surrounding floodplain. Ground-surface altitudes at nodes located where embankments were removed were assigned altitudes of the surrounding floodplain. All specifications of downstream boundary, " $n$ ", discharge, and base eddy viscosity rema in the same as those used in the proposed and alternate design simulations.

\section{Results of the Simulation}

Water-surface altitudes upstream from the embankment and in the areas immediately downstream from the openings in the embankment generally were lower without the embankments in place than in the proposed and alternate design simulations. Small rises in water-surface altitude are computed in areas on the downstream side of the embankment where drawdown occurs with the embankment in place. Water-surface contours for the simulation are shown in figure 17.

The water surface where the highway would be has a lateral slope component, from right bank to left bank. This lateral water-surface slope is an indication of the redistribution of flow across the floodplain that exists when the effect of the highway is not considered. There is about twice as much fall in the reach downstream from the highway crossing than in the reach upstream. The approximate ratio of fall through the upper and lower reaches holds even without the highway embankment in place. Also, in this vicinity ground-surface altitudes above the 50-year flood altitude form a ridge which results in a flow-area reduction for the right bank of the floodplain. This location is noted as the position where the slope change occurs and where contours become more skewed perpendicular to the axis of the floodplain. The effect of this feature on the hydraulics at the crossing site may be a contributing factor on flow through the proposed right overflow opening. This change in water-surface slope is not detected in the WSPRO computations with a downstream-boundary specification of $231 \mathrm{ft}$ because the initial existing design data did not include a cross section representing the floodplain at the location of the ridge.

\section{BACKWATER AND DRAWDOWN}

The amount of backwater and drawdown caused by the highway crossing can be determined by obtaining the difference in water-surface altitude between the simulations with the embankment and without the embankment. The backwater and drawdown caused by the proposed highway crossing is shown in figure 18.

Indications of backwater downstream of an opening is not a response commonly recognized in references on general computation of water-surface profiles, but is a characteristic that has been documented as occurring at crossings of wide floodplains (Schneider and others, 1977). The areas of backwater, downstream from the Texas Highway 43 crossing, are relatively small in magnitude and areal extent. In general, water-surface altitudes rise by 


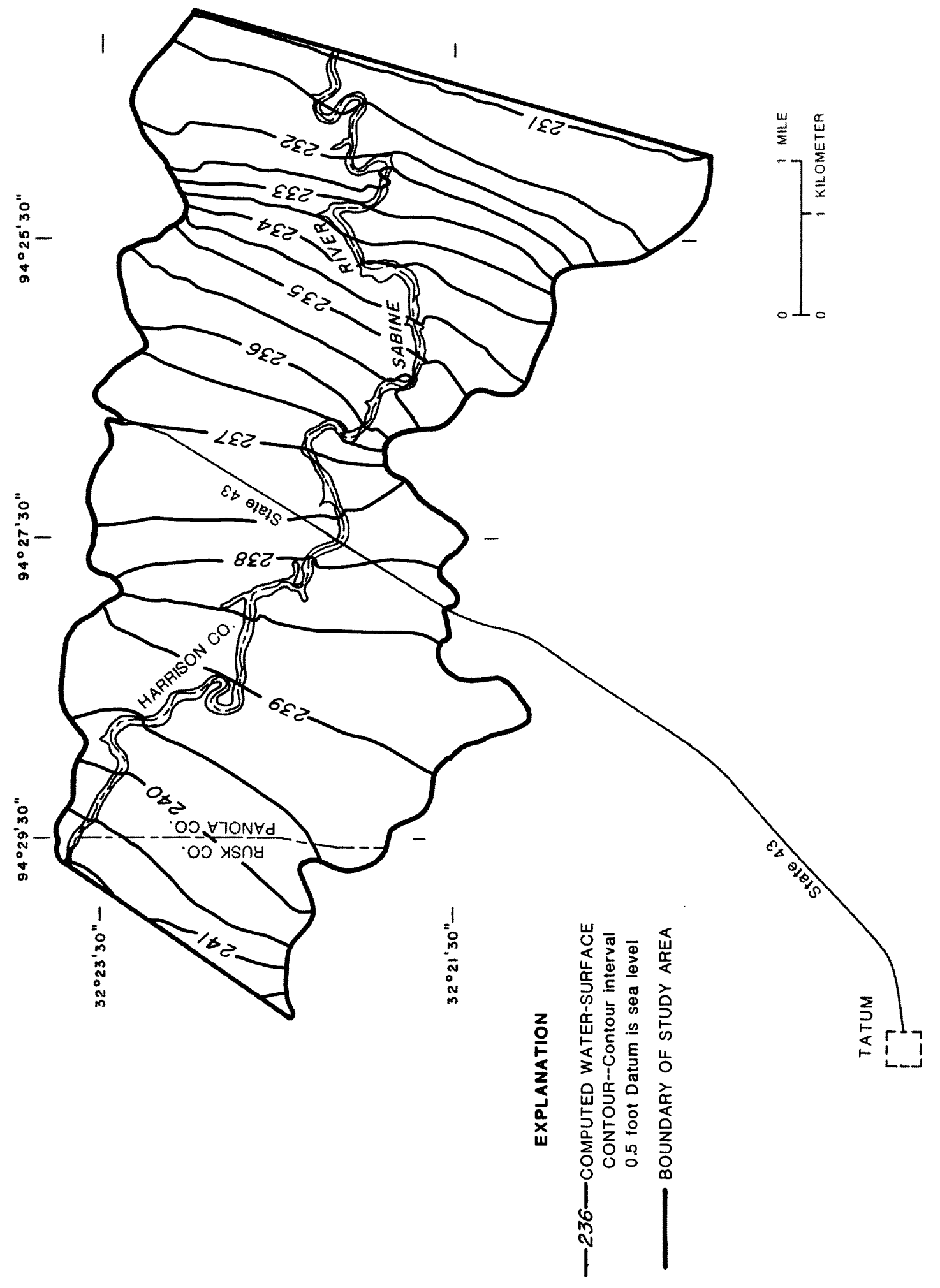

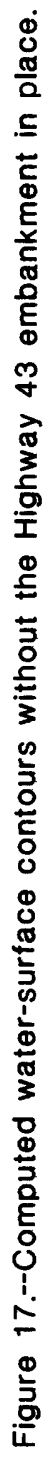




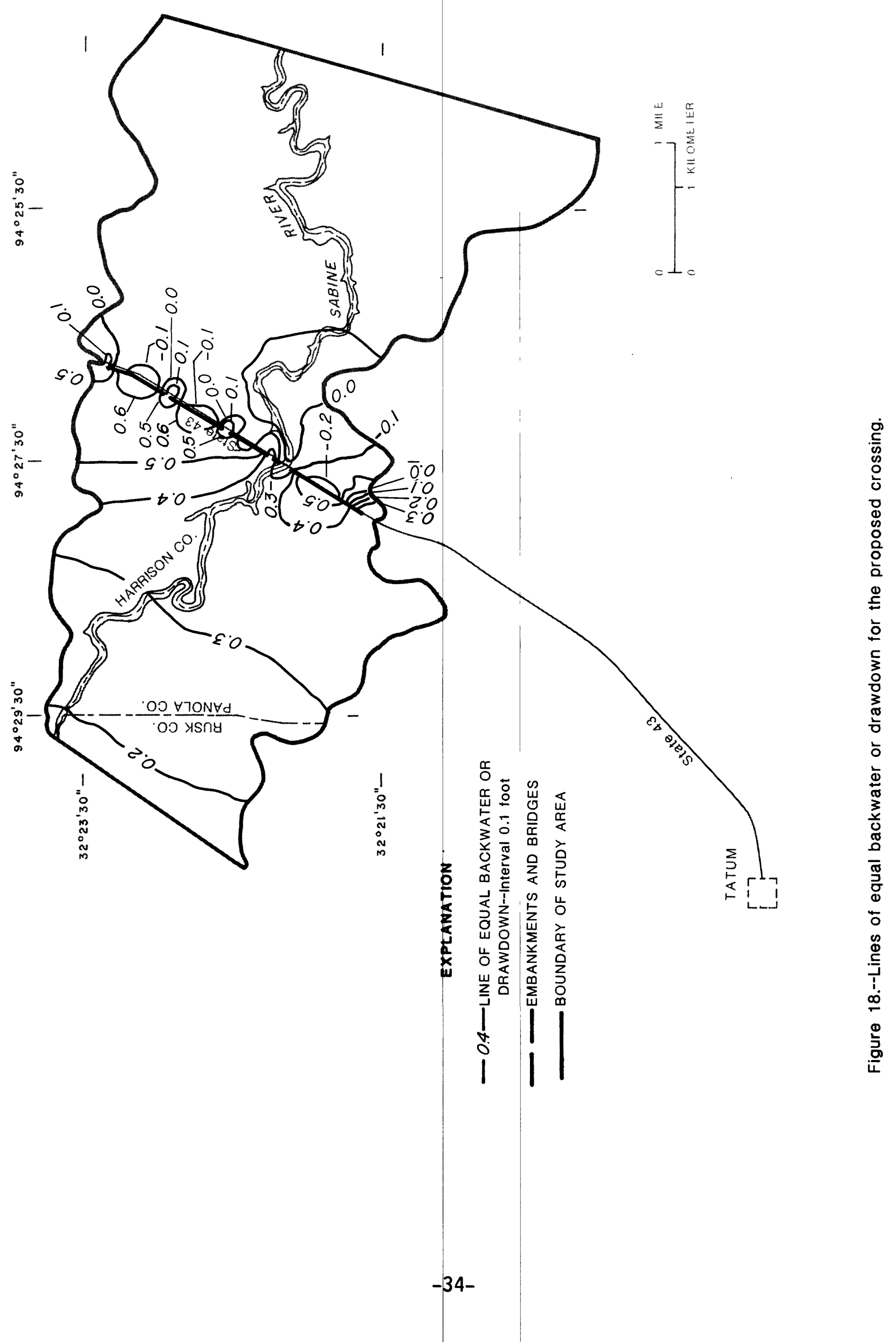


about 0.4 to $0.6 \mathrm{ft}$ in the areas immediately upstream from the embankment compared to the water-surface altitudes without the highway embankment in place, and increases of about $0.2 \mathrm{ft}$ extend to near the upstream boundary.

\section{SUMMARY AND CONCLUSIONS}

The results of simulations of the proposed and alternate highway designs allowed an evaluation of their relative hydraulic performance. The computed values of unit discharge at the right overflow opening are the smallest of all the openings. This is evidence that the right overflow is the least effective per foot of width of all the openings.

The proposed highway crossing shows that the main channel opening and the oxbow opening have the largest values of unit discharge. The smallest values of unit discharge are in the right overflow opening.

The alternate highway design combines the main channel and oxbow openings and reduces the opening of the right overflow producing an improvement in hydraulic efficiency. The alternate design has combined openings of $2,070 \mathrm{ft}$ in comparison to the proposed $1,800 \mathrm{ft}$ and the existing $1,910 \mathrm{ft}$.

In general, velocities computed within the bridge openings were all less than $4 \mathrm{ft} / \mathrm{s}$ at the abutments. The one exception is at the right abutment of the oxbow channel opening where the computed velocity is $5 \mathrm{ft} / \mathrm{s}$. These values of computed velocity are within the acceptable limits of the SDHPT.

The proposed and alternate designs result in computed water-surface a 1titudes upstream from the embankment of up to $0.6 \mathrm{ft}$ above the computed altitudes for natural conditions. The increase is less than $0.2 \mathrm{ft}$ at the upstream boundary for both designs. 


\section{SELECTED REFERENCES}

Bradley, J.N., 1970, Hydraulics of bridge waterways, hydraulic design series No. 1: Federal Highway Administration, Washington, D.C., $111 \mathrm{p}$.

Davidian, Jacob, Carrigan, P.H., Jr., and Shen, John, 1962, Flow through openings in width constrictions: U.S. Geological Survey Water-Supply Paper 13690 , p. $91-122$.

Gilbert, J.J., and Froehlich, D.C., 1987, Simulation of the effect of U.S. Highway 90 on Pearl River floods of April 1980 and April 1983 near Slide11, Louisiana: U.S. Geological Survey Water-Resources Investigations Report 85-4286, $47 \mathrm{p}$.

Gilbert, J.J., and Schuck-Kolben, R.E., 1987, Effects of proposed highwayembankment modifications on water-surface elevations in the lower Pearl River floodplain near Slidell, Louisiana: U.S. Geological Survey WaterResources Investigations Report 86-4129, $36 \mathrm{p}$.

Hulsing, Harry, 1968, Measurement of peak discharge at dams by indirect method: U.S. Geological Survey Techniques of Water-Resources Investigations, book 3, ch. A5, p. 29.

Lee, J.K., Froehlich, D.C., Gilbert, J.J., and Wiche, G.J., 1982, Twodimensional analysis of bridge backwater in Proceedings of the conference, Applying Research to Hydraulic Practice, August 17-20, 1982: Jackson, Mississippi, American Society of Civil Engineers, p. 247-258.

-1983, A two-dimensional finite-element model study of backwater and flow distribution at the I-10 crossing of the Pearl River near S1idell, Louisiana: U.S. Geological Survey Water-Resources Investigations Report $82-4119,66 \mathrm{p}$.

Schneider, V.R., Board, J.W., Colson, B.E., Lee, F.N., and Druffel, Leroy, 1977. Computation of backwater and discharge at width constrictions of heavily vegetated flood plains: U.S. Geological Survey Water-Resources Investigations Report 79-129, $71 \mathrm{p}$.

Shearman, J.0., Kirby, W.H., Schneider, V.R., and Flippo, H.N., 1986, Bridge waterways analysis model: Research Report, FHWA/RD-86/108, 112 p.

Wiche, G.J., Gilbert, J.J., Froehlich, D.C., and Lee, J.K., 1988, Analysis of alternative modifications for reducing backwater at the $\mathrm{I}-10$ crossing of the Pearl River near Slidel1, Louisiana: U.S. Geological Water-Supply Paper 2267.

Wiche, G.J., Gilbert, J.J., and Lee, J.K., 1982, Analysis of alternatives for reducing bridge backwater in Proceedings of the conference, Applying Research to Hydraulic Practice, August 17-20, 1982: Jackson, Mississippi, American Society of Civil Engineers, p. 259-269. 